\title{
Geometry and development of glacial continental margin depositional systems in the Bellingshausen Sea
}

\author{
Frank O. Nitsche ${ }^{\mathrm{a}, *}$, Alex P. Cunningham ${ }^{\mathrm{b}}$, Rob D. Larter ${ }^{\mathrm{b}}$, Karsten Gohl ${ }^{\mathrm{a}, 1}$ \\ a Alfred Wegener Institute for Polar and Marine Research, Columbusstrasse, Bremerhaven D-27568, Germany \\ ${ }^{\mathrm{b}}$ British Antarctic Survey, High Cross, Madingley Road, Cambridge CB3 OET, UK
}

Received 1 December 1998; accepted 4 June 1999

\begin{abstract}
We present multi-channel seismic (MCS) reflection profiles and bathymetry data acquired across a remote and poorly surveyed part of the Antarctic continental margin in the Bellingshausen and Amundsen Seas. This new information has been combined with published data and used to interpret the style of sedimentation on the continental shelf, slope and rise, and to describe sedimentation processes which have been active in this region. Most seismic reflection profiles crossing the continental margin show prograded sequences beneath the outer shelf and upper slope, and we infer that the stratal characteristics of these sequences indicate that grounded ice sheets reached the shelf edge during previous glacial times. Although there are general similarities in stratal geometry on these profiles, in detail, they reveal significant longitudinal variations in sediment input from the shelf to the upper slope. On several profiles, we found evidence of mass wasting of the continental slope in the form of slump and debris flow deposits. At greater depth, turbidity flows, bottom currents and Coriolis force have controlled the further transportation and deposition of sediment, which has resulted in the development of mounds, channels and sediment wave fields. The distribution, and variations in the size and geometry of the mounds reflect sediment input and the relative contribution of these other factors which control sedimentation on the continental rise. (C) 2000 Elsevier Science B.V. All rights reserved.
\end{abstract}

Keywords: Bellingshausen Sea; Amundsen Sea; reflection seismic survey; glacial marine sedimentation; sediment drifts

\section{Introduction}

To understand the climatic history of Antarctica and relate it to proxy records of global sea level and ice volume, we need to know the glacial record

\footnotetext{
* Corresponding author. Institute of Geophysics, ETH Zürich, ETH Hönggerberg, Zürich CH-8093, Switzerland. Fax: +41-1633-1065; E-mail: frankn@aug.ig.erdw.ethz.ch

${ }^{1}$ Present address: Macquarie University, Department of Earth and Planetary Sciences, Sydney NSW 2109, Australia.
}

preserved in sediment derived from Antarctica (e.g., Miller et al., 1987; Cooper and Webb, 1992). Studies on the Antarctic continental shelves (e.g., Antarctic Peninsula: Bart and Anderson, 1995; Larter et al., 1997; Ross Sea: De Santis et al., 1995) show that the sediments there are unlikely to contain a complete record. Sediments deposited during earlier glacial advances might have been partially or completely eroded by later glacial advances. Also, ice might not have covered all parts of the continental shelf during some glacial periods, so that the proximal glacial sediment record may be incomplete. As a conse- 


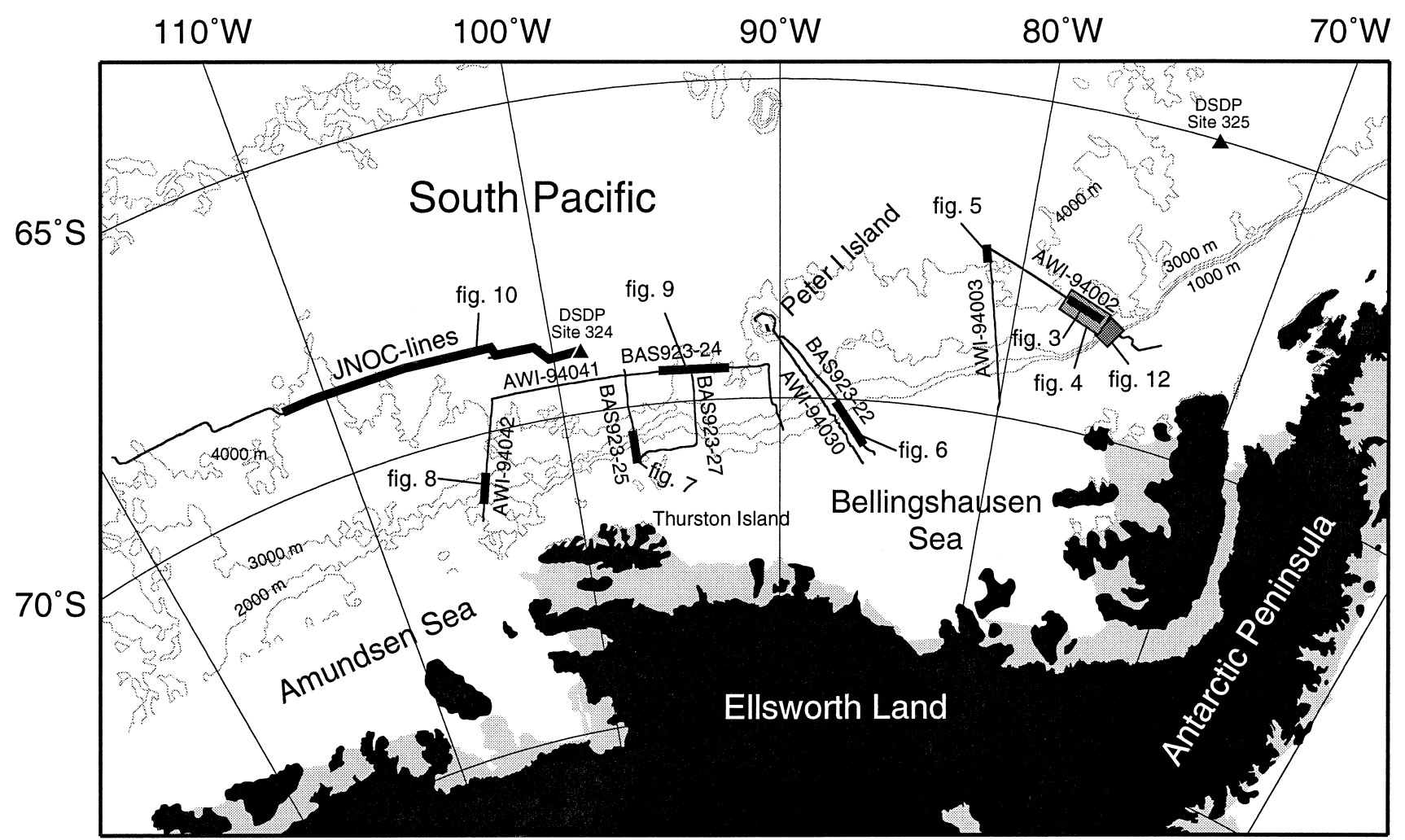

Fig. 1. Location map showing the area investigated in this study. Bathymetry (Smith and Sandwell, 1997) is contoured at 1000-m intervals. MCS profiles are shown as thin black lines; thick lines locate seismic sections reproduced in this paper; grey boxes show swath bathymetry images. Grey areas near the coast are floating ice shelves. 
quence, diverse types of sediment accumulations reported on the continental rise (e.g., drifts along the Antarctic Peninsula: McGinnis and Hayes, 1995; Rebesco et al., 1996; drifts and turbidites off Prydz Bay: Kuvaas and Leitchenkov, 1992; Crary fan in the Weddell Sea: Moons et al., 1992) are becoming increasingly important because they can contain a more complete and more easily recoverable palaeoenvironmental record. However, a full understanding of continental rise sedimentation requires some knowledge of shelf and slope depositional processes; e.g., information about the volume and type of sediment supplied to the upper slope, and the variation of these parameters with time. To understand the sedimentary record of the rise, the whole sediment transport path from shelf to slope to rise must be understood.

Owing to its remoteness, the Antarctic continental margin in the Bellingshausen and the Amundsen Seas has been poorly surveyed, and consequently, the glacial history of the neighbouring Ross Sea and Antarctic Peninsula regions is better understood (Fig. 1). Studies of the eastern Ross Sea suggest that large ice sheets first extended onto the continental shelf in the early Miocene (De Santis et al., 1995), whereas studies of the shelf west of the Antarctic Peninsula suggest that grounded ice did not extend onto the outer continental shelf there until late Miocene (Larter et al., 1997). It seems unlikely that extensive ice sheets would have developed on the Bellingshausen Sea shelf earlier than in the Ross Sea, and it is possible that they did not develop before ice sheets on the Antarctic Peninsula shelf.

Sediment distribution in the Bellingshausen Sea has also been affected by the tectonic evolution of the region, as discussed by Tucholke and Houtz (1976). Plate tectonic reconstructions (Mayes et al., 1990; McCarron and Larter, 1998) indicate that this section of the West Antarctic margin can be divided into two parts. The western part is a rifted margin conjugate to Chatham Rise, which separated from West Antarctica between 90 and $85 \mathrm{Ma}$ ago. The eastern part was an active margin and subduction continued until the Antarctic-Phoenix spreading ridge segments migrated into the trench during the Tertiary. This sequence of ridge-trench collisions took place along the Antarctic Peninsula margin from the Middle Eocene or earlier until Pliocene times (Larter and Barker, 1991a; McCarron and Larter, 1998). The boundary between the rifted margin and the part of the margin where the ridge-trench collision took place lies somewhere between $85^{\circ}$ and $105^{\circ} \mathrm{W}$ (McCarron and Larter, 1998). Hence, ocean floor age varies considerably within the study area, and this provides a constraint on the maximum age of overlying rise sediments. It is likely also, that the Antarctic-Phoenix ridge acted as a barrier to the northwestward transport of terrigenous sediment until it migrated into the trench, so the earliest sediments on the Bellingshausen Sea continental rise are likely to be a condensed sequence.

In this paper, we use reconnaissance multi-channel seismic reflection (MCS) and swath bathymetry data to describe the distribution and pattern of accumulation of glacigenic sediments from the outer shelf to the rise in the Bellingshausen and Amundsen Seas. We also consider how the observed pattern of accumulation is influenced by factors such as the length of the glacial drainage pathway, the lateral variability of ice input to the shelf, and the distal position of the rise in this area from presumed sources of bottom water. Previous studies of sedimentary features in this region were based on sparse, analogue single-channel seismic profiles (Tucholke, 1977), or were restricted mainly to the area west of $104^{\circ} \mathrm{W}$ (Yamaguchi et al., 1988). More recently, Cunningham et al. (1994) and Nitsche et al. (1997) reported the existence of prograding sequences on MCS lines crossing the Bellingshausen and Amundsen Seas continental margins, and observed that there are striking similarities in the general stratal patterns.

\section{Data}

\subsection{Bathymetry and sub-bottom profile data}

Compilations of marine geophysical data (e.g., National Geophysical Data Center, 1996) show a paucity of ship tracks in the Bellingshausen and Amundsen Seas. As a consequence, bathymetry maps derived solely from these sparse shipboard measurements (e.g., GEBCO: Mammerickx and Cande, 1982) do not describe sea-floor topography of the region in great detail. In this study, we combine new track and 

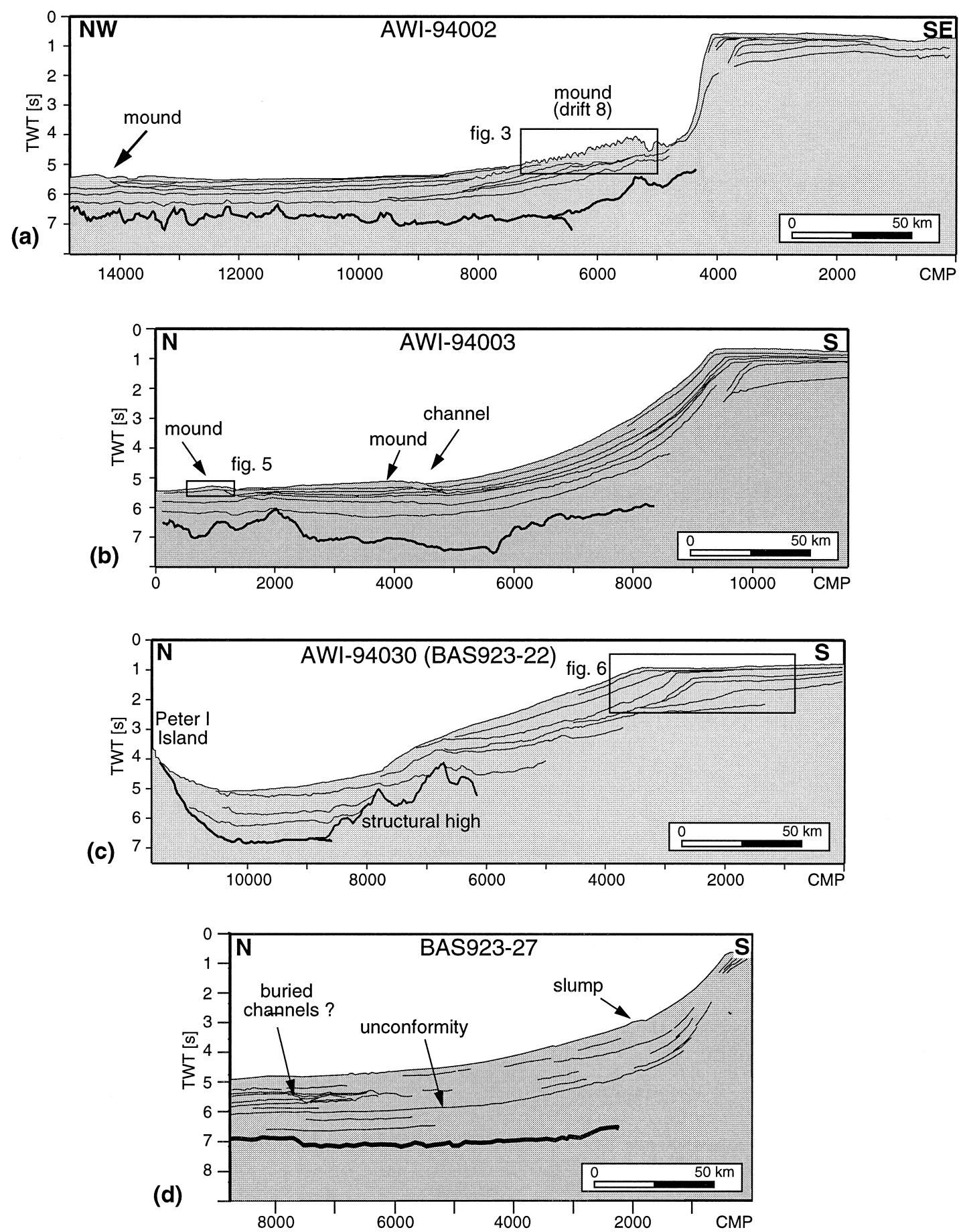

Fig. 2. Interpreted line drawings of MCS profiles (located in Fig. 1). (a) to (f) show a series of MCS transects which extends across the Antarctic continental margin progressively from east to west. $(\mathrm{g})$ shows a profile on the continental rise which runs parallel to the margin. All profiles are drawn with the same scale and vertical exaggeration (ca. 16:1 at the sea floor). Bold lines represent reflections that correspond to the top of the acoustic basement. 
(e)
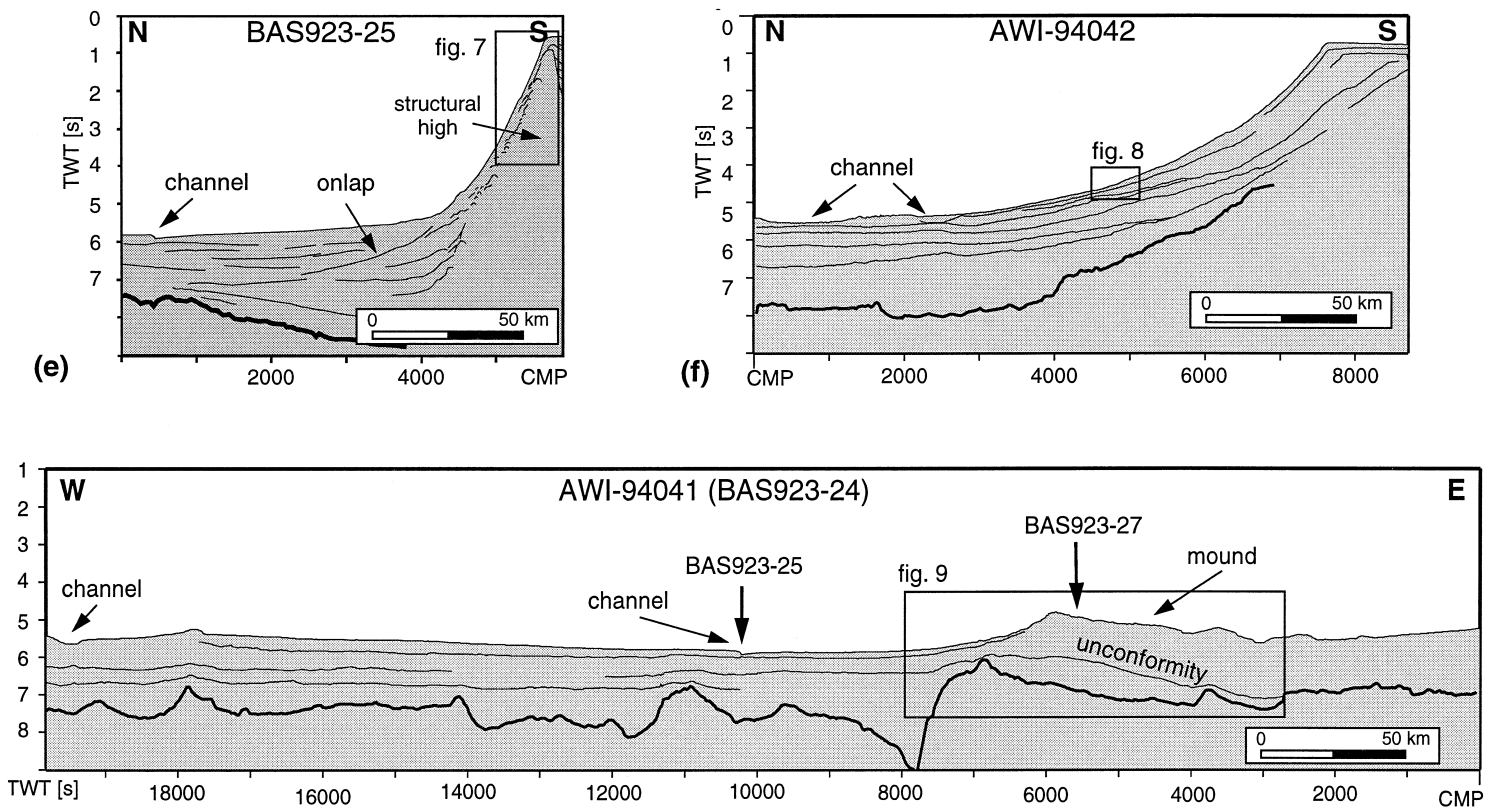

(g)

Fig. 2 (continued).

swath bathymetry data acquired by the British Antarctic Survey (BAS) and the Alfred Wegener Institute for Polar and Marine Research (AWI) across the Antarctic continental shelf, slope and rise. These data have been used to determine the orientation and extent of sea-floor features apparent in seismic reflection profiles, and to describe sea-floor morphology in areas beyond the MCS surveys. In addition, interpretations of BAS and AWI data have been conducted with reference to the predicted sea-floor topography of Smith and Sandwell (1997), generated by combining satellite altimetry data with existing bathymetric soundings. Comparison of the predicted topography with our new data suggests that the predicted surface describes the position and shape of sea-floor features (at 15-160 km wavelength, to $\left.72^{\circ} \mathrm{S}\right)$ quite well, where shipboard soundings are absent. However, the predicted topography of the Antarctic continental shelf should be interpreted with care, because few soundings have been incorporated in the data near its southern limit, and therefore, the satellite-derived component is poorly constrained in this area.
BAS and AWI have also collected $3.5 \mathrm{kHz}$ and 'Parasound' sub-bottom profiles. These high-resolution profile data were used to map channel paths and sediment waves, and to help distinguish areas of modern deposition and non-deposition.

\subsection{Seismic reflection data}

BAS and AWI have acquired MCS profiles across the Antarctic continental margin in the Bellingshausen and Amundsen Seas during three scientific cruises: BAS cruise JR04 (1992/1993, Cunningham et al., 1994) conducted on RRS James Clark Ross, and AWI cruises ANT 11/3 (1994) and ANT 12/4 (1995) conducted on RV Polarstern (Miller and Grobe, 1996). During these cruises, ca. 1500 line km of MCS data were acquired by BAS and ca. 3400 line $\mathrm{km}$ of MCS data were acquired by AWI. In this study, we present a subset of these data totalling ca. 2700 line $\mathrm{km}$, which extends across the Antarctic continental margin between $76^{\circ} \mathrm{W}$ and $105^{\circ} \mathrm{W}$. BAS MCS profiles were acquired using an airgun source with a combined chamber capacity of ca. 55.91 , and 
a streamer with an active length of $2400 \mathrm{~m}$. AWI MCS profiles were acquired using an airgun source with a combined chamber capacity of ca. 241 , and a streamer with active lengths of either 2400 or $600 \mathrm{~m}$.

As part of this study, we also describe MCS profiles acquired by the Japan National Oil (JNOC), published through the SCAR-database (Yamaguchi et al., 1988; SCAR, 1992). Most MCS profiles extend across the outer continental shelf, slope and rise (Fig. 1). However, we also include BAS and AWI profiles AWI-94041/BAS923-24, and JNOC profiles TH-86002 and TH-86003 which lie nearly parallel to the continental margin. Fig. $2 \mathrm{a}-\mathrm{g}$ show interpreted line drawings of these data.

BAS and AWI MCS profiles presented in this study have been processed using standard seismic processing procedures including trace editing, deconvolution, velocity analysis, normal moveout correction, bandpass frequency filtering, stack and migration. All lines have a CMP spacing of $25 \mathrm{~m}$.

\section{Interpretation of seismic reflection profiles and bathymetry data}

\subsection{AWI-94002}

MCS profile AWI-94002 is the easternmost line described in this study (Figs. 1 and 2a). AWI-94002 crosses the Antarctic continental margin near $76^{\circ} \mathrm{W}$, and shows a steep continental slope, with a gradient (ca. $13^{\circ}$ ) comparable to that observed on many lines crossing the Pacific margin of the Antarctic Peninsula to the northeast (Larter and Barker, 1991b; Larter and Cunningham, 1993). On the outer continental shelf, three different acoustic-stratigraphic units can be distinguished on the basis of their geometry and internal reflection configuration (Units 1-3 of Nitsche et al., 1997). The lowermost unit is composed of comparatively gently dipping strata, which formed a mainly aggradational shelf. In contrast, the upper two units show steeper slopes and a more progradational geometry, which has resulted in a seaward migration of the continental shelf break of ca. $15 \mathrm{~km}$. The middle unit (Unit 2 of Nitsche et al., 1997) clearly shows erosional truncation of foreset reflections beneath a series of sub-horizontal unconformities. These reflection geometries resemble those of units S1, S2 and S3 reported by Larter and Barker (1989) along the continental margin of the Antarctic Peninsula (although numbered in the opposite sense). We note, however, that equivalent units in the two provinces are not necessarily coeval.

Farther north, profile AWI-94002 extends across the Antarctic continental slope and rise. Here, the irregular top of oceanic acoustic basement is clearly imaged between 5 and $7 \mathrm{~s}$ two-way time (STWT). We confidently trace this surface southward from the end of line to ca. CMP 4500 (beneath the lower continental slope, Fig. 2a). At shallower depth, we identify two separate mounds developed within the overlying sedimentary succession. Between CMPs 5250 and 8000 , the largest mound extends northward from the base of the continental slope (Figs. 3 and 4). This structure has been identified by Rebesco et al. (1996) as a sediment drift (their drift ' 8 ', imaged on MCS profile IT92-109). Profile AWI-94002 (Fig. $2 \mathrm{a}$ and Fig. 3) and accompanying swath bathymetry data (Fig. 4) show that most of the drifts are separated from the continental margin by a large channel (between CMPs 5100 and 5250, Fig. 3). Also, Figs. 3 and 4 show that this part of the drift has been dissected by several small erosional gullies, which suggests that erosion has progressed more quickly than recent deposition at this locality. Farther north (between CMPs 7500 and 8500, Fig. 2a), younger sediments cover and in-fill the erosional gullies. Part of this mound is shown in cross-section by Rebesco et al. (1996) in their seismic line IT92-109. This profile shows an acoustic-stratigraphic boundary within the mound, overlain by sediments which we interpret as correlating with the gully fill sediments seen on line AWI-94002. This interpretation is supported by swath bathymetry data (reproduced in perspective view, Fig. 4) which show a gradual northward suppression of gullied topography towards the intersection of profiles AWI-94002 and IT92-109. The origin of these gullies is uncertain; it is possible that they formed by small-scale slumping of the unstable northern slope of the mound into the adjacent channel.

On the lower rise, at a distance of 200-250 km from the Antarctic continental slope (between CMPs 13500 and 14900, Fig. 2a), a separate, smaller sediment mound is seen. This smaller mound does not show any clear signs of gullying or slope failure. 


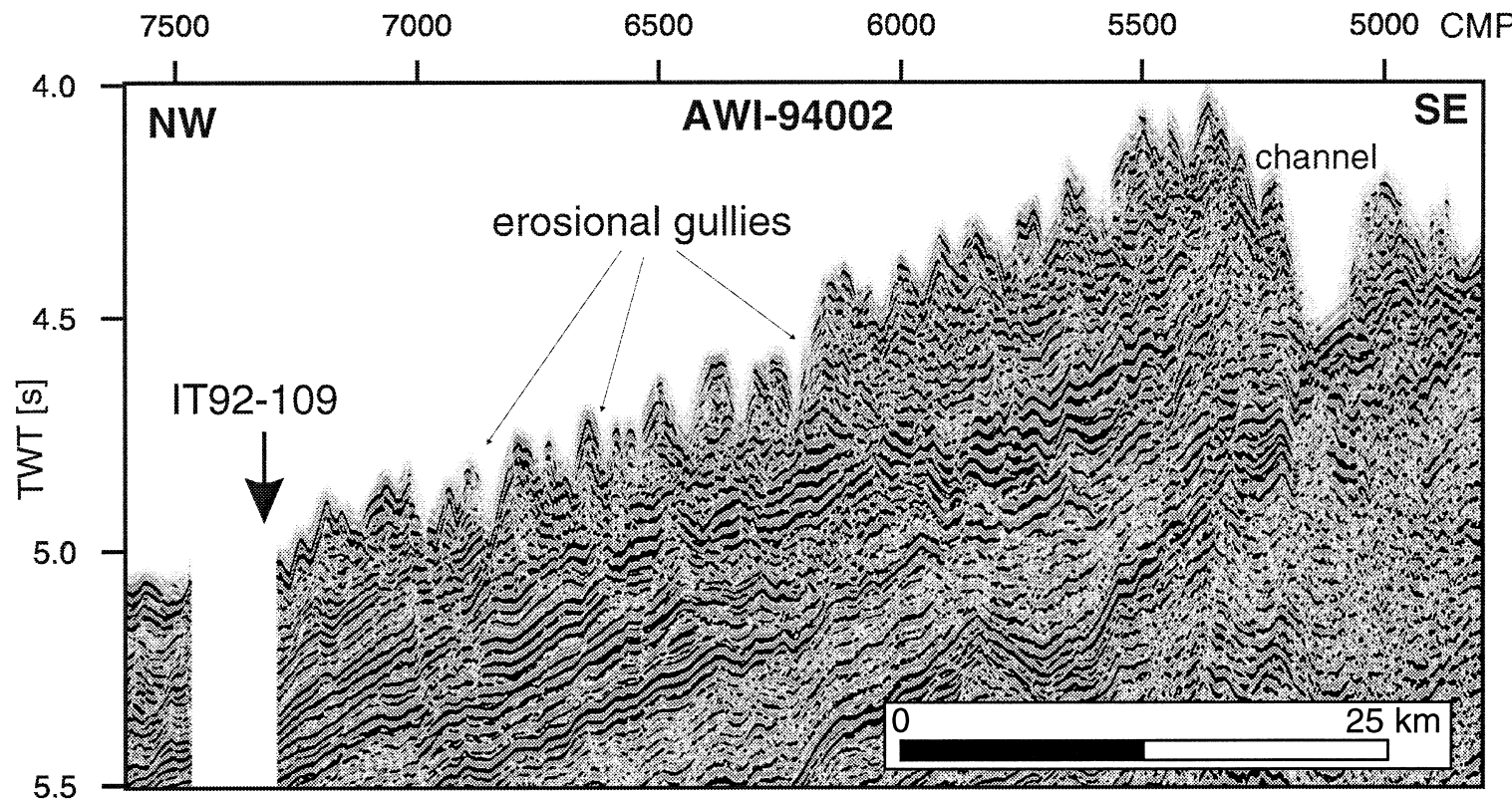

Fig. 3. Part of MCS profile AWI-94002 (located in Fig. 1) showing a cross-section of the large mound on the upper continental rise (vertical exaggeration ca. 30:1 at the sea floor). The profile lies close to the crest of the mound (compare Fig. 4).

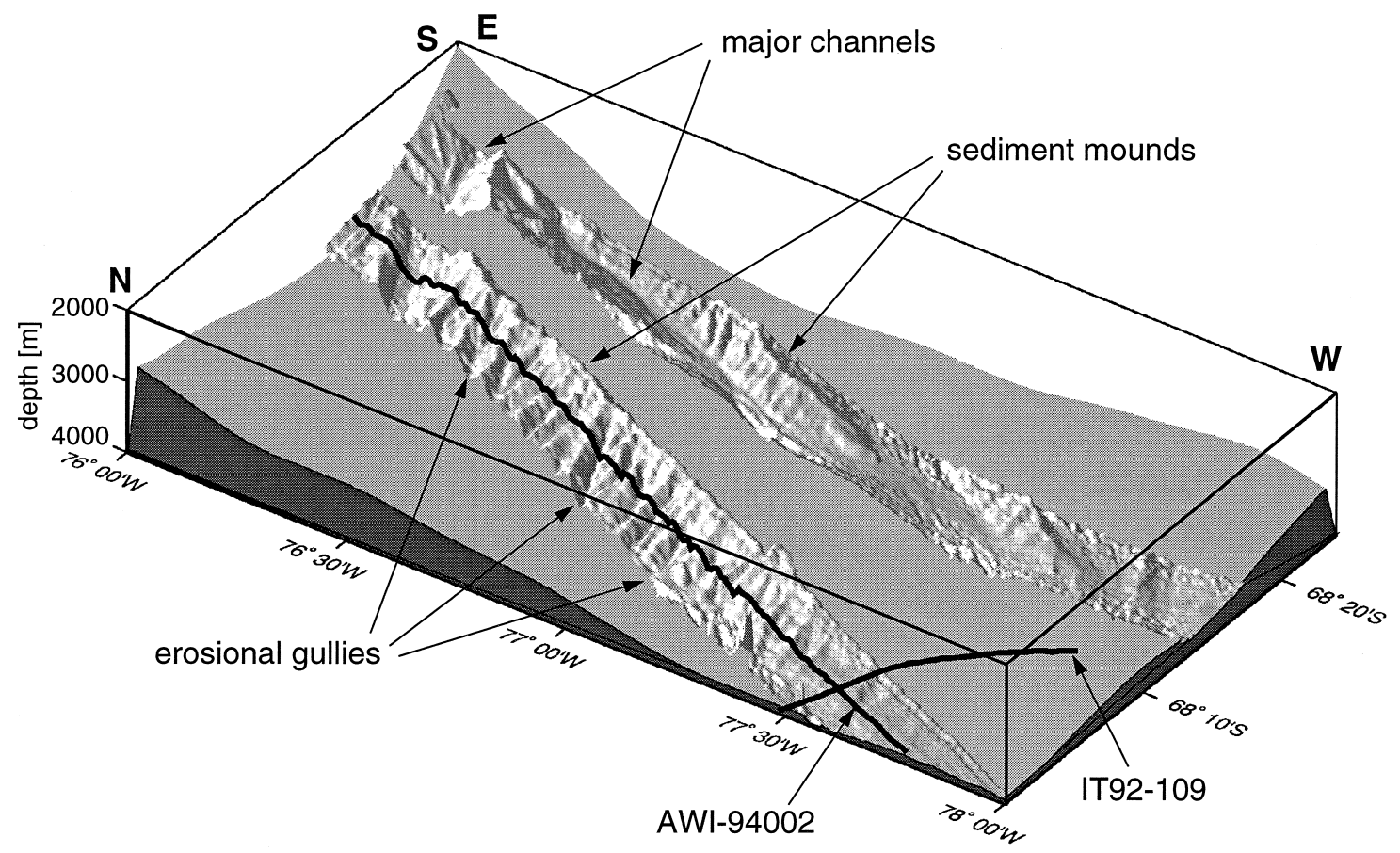

Fig. 4. Perspective view of two Hydrosweep swath bathymetry stripes from the continental rise north of Alexander Island (located in Fig. 1). These data are illuminated from NE. The northern stripe was obtained along MCS profile AWI-94002 (located with a thick black line, and shown in Fig. 3). The line extending nearly perpendicular to the strip locates MCS profile IT92-109 of Rebesco et al. (1996; 1997). The data show small gullies which have been progressively filled toward the NW. 
Instead, sub-bottom profile data suggest that it is a site of modern deposition, and show well-formed migrating sediment waves at its surface (imaged also along nearby profile AWI-94003, Fig. 5). Accompanying swath bathymetry data show that the crests of the waves are orientated in a NE-SW direction.

MCS profile AWI-94002 shows that neither mound is built directly upon oceanic acoustic basement; the base of both mounds is separated from the basement by an intervening sedimentary layer with a time-thickness of 0.5-1.0 STWT. The reflection configuration of this layer differs from that of the mounds; underlying strata typically show more uniform, parallel to sub-parallel, lower-amplitude reflections. An equivalent older or 'pre-drift stage' of sedimentation has been reported by McGinnis and Hayes (1995) and Rebesco et al. (1996) for the mounds they identified on the continental rise to the northeast.

\subsection{AWI-94003}

Profile AWI-94003 extends SSE from the end of line AWI-94002, across the continental rise and slope, and crosses the shelf break near $80^{\circ} \mathrm{W}$ (Figs. 1 and 2b). On AWI-94003, the acoustic architecture of the outer shelf resembles that observed farther east (on profile AWI-94002, Fig. 2a), and shows a change from a mainly aggradational to a progradational ge- ometry (Nitsche et al., 1997). Here, foreset progradation has resulted in a seaward migration of the continental shelf break of $20 \mathrm{~km}$ (between CMPs 9300 and 10100, Fig. 2b). In contrast to AWI-94002, the continental slope on AWI-94003 has a comparatively gentle dip of ca. $3^{\circ}$. Here also, the prograded wedge clearly extends beneath the continental slope (Fig. 2b and Fig. 5 of Nitsche et al., 1997), and farther north (near CMP 4500, Fig. 2b), the toe of the prograded wedge thins against a low relief sediment mound developed on the upper continental rise (between CMPs 2500 and 4500, Fig. 2b). On the continental slope, several packages of chaotic and discontinuous reflections can be seen at shallow depth, which resemble those shown in Fig. 8. These acoustically chaotic packages are thought to represent debris flow deposits. At the northern end of the line, AWI-94003 shows a second, separate sediment mound (between CMPs 1 and 1350, Fig. 2b). This more northerly mound is also seen at the northern end of line AWI-94002. On profile AWI-94003, the mound shows fine acoustic lamination; older mound sediments show uniform, parallel to sub-parallel reflections, whereas younger mound units show a migrating-wave acoustic facies (e.g., Fig. 6 of Nitsche et al., 1997) which extends to the surface of the mound. High-resolution sub-bottom data (Fig. 5) show these bedforms in more detail, and suggest that the sediment waves are probably active. Swath

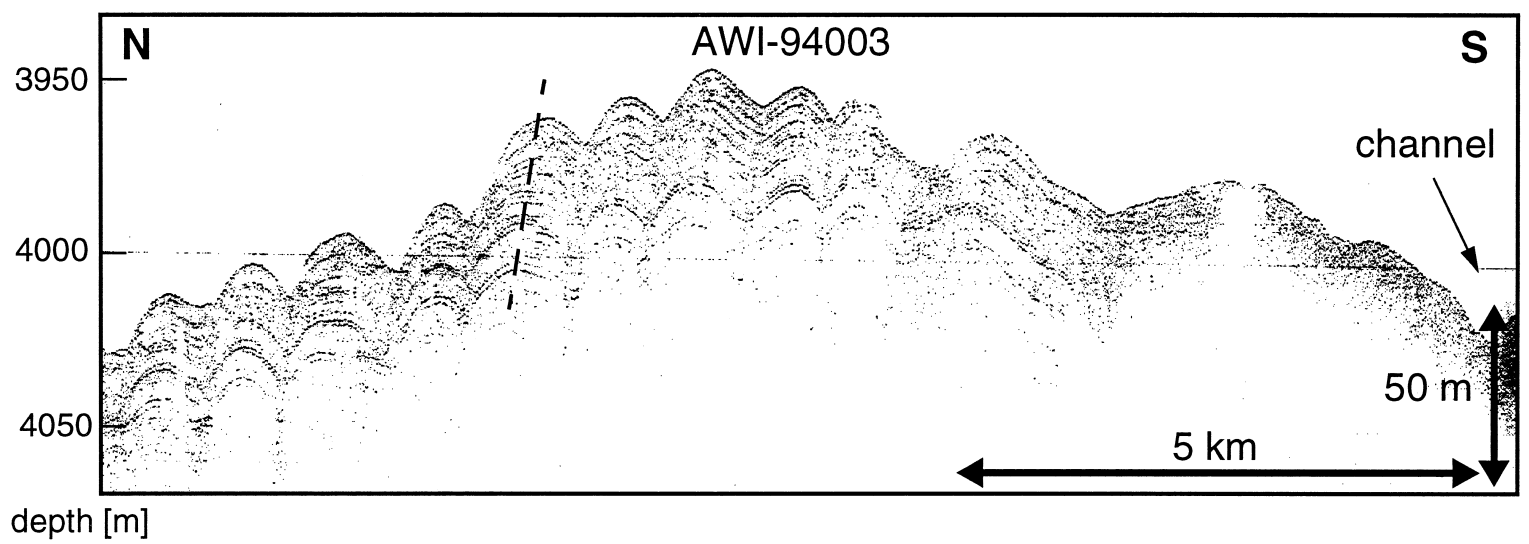

Fig. 5. Parasound high-resolution sub-bottom profile of the sediment mound at the northern end of MCS line AWI-94003 (located in Fig. 1). The mound is also seen at the northwestern end of MCS profile AWI-94002. Sub-bottom penetration is ca. $50 \mathrm{~m}$. This profile shows sediment waves (wavelengths of $850-900 \mathrm{~m}$ ) with a south component of migration towards an adjacent channel. Coincident swath bathymetry data suggest that waves trend obliquely to the profile, and have a true migration direction towards the southeast. 


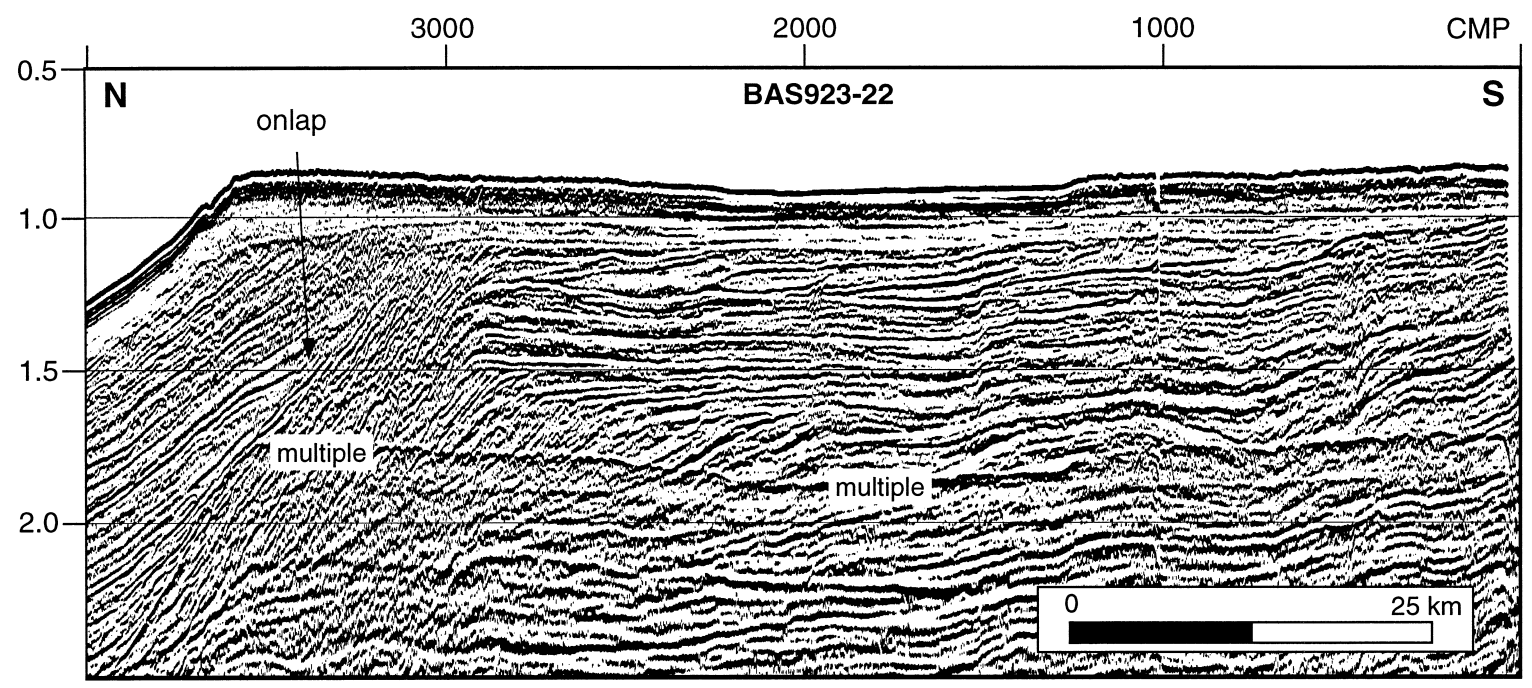

TWT [s]

Fig. 6. Section from MCS profile BAS923-22 (located in Fig. 1) showing the outer continental shelf near $87^{\circ} 30^{\prime} \mathrm{W}$. Vertical exaggeration is ca. $24: 1$ at the sea floor.

bathymetry data combined with seismic lines AWI94002 and AWI-94003 show that the sediment waves have migrated southeastward, toward an adjacent channel (near CMP 1350, Fig. 2b). On profile AWI94003, channels lie along the southern edge of both sediment mounds, and accompanying swath bathymetry data show that these channels obliquely cross the seismic line. As observed on nearby profile AWI-94002, AWI-94003 shows that the sediment mounds are separated from basement by an older sediment sequence with a thickness of $0.5-1.7$ STWT.

\subsection{BAS923-22 and AWI-94030}

Farther west, MCS profiles BAS923-22 and AWI94030 trend NW-SE and cross the continental shelf break near $87^{\circ} 30^{\prime} \mathrm{W}$ (Figs. 1 and 2c). These profiles lie less than $25 \mathrm{~km}$ apart (Fig. 1), and show similar successions of depositional sequences. Here, we calculated a depth of the shelf break between $630 \mathrm{~m}$ (on profile BAS923-22) and $680 \mathrm{~m}$ (on profile AWI94030) below sea level from the seismic sections using a water velocity of $1500 \mathrm{~m} \mathrm{~s}^{-1}$. Across the outermost $20-30 \mathrm{~km}$ of the continental shelf, both MCS profiles show that the sea floor deepens gradually landward. Farther inshore, however, the sea floor shallows towards the southern end of both MCS profiles. The acoustic architecture of the outer shelf on these lines (shown in detail, Fig. 6) is more complex than that described elsewhere in this study; while we identify a general trend from an aggradational to a progradational geometry, the transition is not as clear as on other lines (Nitsche et al., 1997). Profile BAS923-22 shows aggradational units overlain by a first set of prograded foresets (e.g., between 1.7 and 1.5 STWT, CMPs 2200-2900, Fig. 6). These older prograded forests are overlain by a mainly aggradational sub-unit represented by vertically stacked palaeo-shelf breaks near CMP 2900 (between 1.5 and 1.2 STWT, Fig. 6), which is overlain in turn by a second series of prograded foresets (e.g., above 1.2 STWT at CMP 2900, Fig. 6). These sub-units are all incorporated within units ' 1 ' and ' 2 ' of Nitsche et al. (1997).

At 1.2 STWT (e.g., at CMP 2800, Fig. 6), profile BAS923-22 shows an unusual unconformity which set back the offlap break more than $60 \mathrm{~km}$ landwards. Downlapping onto this unconformity, prograded foresets record the readvance of the offlap break towards its previous position at CMP 2900. The reason for this remarkable landward movement of the offlap break is unclear, although we propose different scenarios which might result in the devel- 
opment of such a structure. This geometry may have been caused by a long interruption in glacial sediment supply to this part of the margin during which time the shelf subsided. Alternatively, it may reflect a short period of rapid local subsidence during the deposition of glacial margin sequences. It is possible also that this geometry could reflect a local change in glacial regime, leading to thinner grounded ice sheets, perhaps resulting from a change in glacial catchment area, or other factors controlling glacial flow. On profiles BAS923-22 and AWI-94030, the sequence of stratal geometry transitions (aggradation-progradation-aggradation-retrogradation-pro gradation) reflects the balance between sediment supply and the generation of accommodation space, and shows that, for a period of time, accommodation outstripped sediment supply to this part of the margin. However, it is not possible to unravel the relative effects of sediment supply, subsidence and ice grounding depth without additional information.

Profiles BAS923-22 and AWI-94030 also show a distinct change in the geometry and acoustic facies of sediments preserved below the outermost shelf and slope. North of CMP 3000 (Fig. 6), high-amplitude, high-frequency, fairly continuous reflections onlap more steeply dipping strata deposited during the second phase of progradation described above. The reflection characteristics of these younger sediments contrast with those of the underlying foresets, which show more irregular, less continuous reflections. At shallower depth (e.g., at 1.1 STWT near CMP 3480, Fig. 6), younger reflections in this onlapping sequence are erosionally truncated at their upper limit. The origin of this onlapping and partly truncated sequence north of CMP 3000 remains uncertain, although we suspect that it mostly consists of mud and silt deposited by ambient bottom currents flowing along the continental slope. A potential source of sediment is a large sediment ridge or mound east of these lines indicated in the bathymetry data (Figs. 1 and 11). It is noteworthy also, that palaeo-slope angles in this unit are $1^{\circ}-2^{\circ}$, considerably less than those of the underlying foresets, and that these sediments underlie the most gently dipping part of the continental slope in this region.

Farther north, profiles BAS923-22 and AWI94030 show two separate structural highs located beneath the lowermost continental slope and the continental rise (Fig. 2c). The northernmost structural high represents the buried southern flank of Peter I Island (between CMP 10500 and the northern end of profile AWI-94030, Fig. 2c). Here, sediments deposited on the adjacent ocean floor onlap the volcanic base of the island. A separate structural high is seen beneath the base of the continental slope (between CMPs 6000 and 8500, Fig. 2c). On profile BAS923-22, this structure shows a chaotic internal reflection configuration, with few coherent, laterally persistent reflections. On nearby profile AWI-94030, this structural high also has a chaotic reflection configuration, although acoustically stratified layers are seen at shallow depths within it. Gravity profiles along the seismic tracks show a negative free-air anomaly over this feature, suggesting that it is composed of deformed sediment rather than oceanic basement. In contrast to MCS lines farther east, profiles BAS923-22 and AWI-94030 show no sediment mounds or channels on the continental rise.

\subsection{BAS923-27}

MCS profile BAS923-27 lies nearly $\mathrm{N}-\mathrm{S}$ and extends across the outer continental shelf, slope and rise near $94^{\circ} \mathrm{W}$ (Figs. 1 and $2 \mathrm{~d}$ ). At its southern limit, BAS923-27 crosses only the outermost $6 \mathrm{~km}$ of the continental shelf, and consequently, it is not possible to infer much about the stratal geometry of the shelf in this area. Nonetheless, these data do show prograded foresets and a sub-horizontal erosional unconformity at shallow depth, resembling those on the other lines. On profile BAS923-27, the continental slope has a dip of $6^{\circ}-7^{\circ}$. Sediments deposited on the slope show high-amplitude reflections that are fairly continuous in the dip direction, and we believe that the slope is primarily constructed of debris flow deposits. On the mid-lower slope (e.g near CMP 2000, Fig. 2d), there is some indication of small-scale slumping.

Farther north, profile BAS923-27 crosses the continental rise close to the crest of a large sediment mound (represented by a northward loop in the 4000 $\mathrm{m}$ isobath, Fig. 1). Here, smooth oceanic basement is overlain by a seismic stratigraphic sequence with a time-thickness of 1.0-1.2 STWT. This lower sequence is characterised by parallel-to-sub-parallel continuous reflections, and shows no indication of 
migrating sediment waves or buried channel systems. The top boundary of this sequence is marked by a continuous, high-amplitude reflection which can be traced from the northern end of the line (at ca. 6 STWT, Fig. 2d) southward beneath the rise and lower continental slope (to about CMP 1200, Fig. $2 \mathrm{~d})$. The sequence boundary appears to be conformably overlain by younger rise sediments on this line. However, E-W-trending MCS profiles AWI94041/BAS923-24 (described below, and shown in Fig. 9), which intersect line BAS923-27 near its northern end, show the unconformable nature of this sequence boundary more clearly. This unconformity is overlain by a sequence with a time-thickness of 1.0-1.2 STWT, which extends to the sea floor, and shows less continuous reflections. Between CMPs 6000 and 8000 (Fig. 2d), BAS923-27 shows local truncation of horizontally layered strata in this upper sequence. This pattern resembles a channel 'cutand-fill' reflection configuration, and may indeed describe a buried channel system. Alternatively, these structures may represent listric fault planes which have been crossed at a low angle by the seismic profile. Listric faults are clearly seen in the intersecting E-W lines AWI-94041/BAS923-24 (described below, and shown in Fig. 9), and these profiles confirm that BAS923-27 runs close to the crest of a large mound or sediment drift (profile intersection marked, Fig. 9). Profile BAS923-27 also shows irregularities at or near the sea floor. The low resolution of the MCS profile prevents confident identification of these surficial features; they could represent sediment waves, channels, gullies or slump scars.

\subsection{BAS923-25}

MCS profile BAS923-25 trends N-S and crosses the Antarctic continental shelf, slope and rise near $97^{\circ} \mathrm{W}$ (Figs. 1 and 2e). The acoustic architecture of the outer shelf and slope on this profile differs markedly from that observed elsewhere within the area of survey. Here, prograded foresets are absent, and the outer continental shelf is underlain by a structural high which appears acoustically chaotic, with no coherent internal structure (centered on CMP 5750, Fig. 7). This structure rises to 0.2 STWT below the sea floor. On unmigrated profiles, the structural high beneath the shelf and the steep conti- nental slope $\left(\right.$ gradient $\left.=7^{\circ}-9^{\circ}\right)$ show numerous strong diffractions. Beneath the slope, diffractions are generated by discontinuities associated with slope failure (slumps, and perhaps debris flows), and at greater depth, by deformed and contorted structure. In contrast to MCS profiles acquired nearby, profile BAS923-25 does not show prograded foresets beneath the outer continental shelf. Instead, shelf strata onlap the southern flank of the marginal high (e.g., at 0.8 STWT south of CMP 5750, Fig. 7).

Farther north, profile BAS923-25 crosses the continental rise. Here, the oceanic basement dips towards the continental margin, and is overlain by a sedimentary sequence of uniform thickness $(0.5-0.7$ STWT), characterised by parallel reflections which follow the dip of basement (e.g., below 7.9 STWT near CMP 3000, Fig. 2e). This lower sequence is overlain by a middle sequence that thickens appreciably towards the margin and shows strongly divergent reflections (e.g., between 6.6 and 7.9 STWT at CMP 3000, Fig. 2e), which suggests syn-tectonic deposition. The middle sequence is overlain, in turn, by an upper acoustic sequence, characterised by sub-parallel, fairly continuous reflections (e.g., between 6.6 STWT and the sea floor at CMP 3000, Fig. 2e). The upper sequence shows basal onlap (labelled in Fig. 2e) against a prominent unconformity which extends northward beneath the rise from the base of the continental slope. On profile BAS923-25, the stratal geometry and thickness of the individual sequences suggest that the lower sequence was deposited before the basement was tilted to the south, and that deposition of the middle sequence accompanied basement tectonism. At present, we do not know when, or by what means, this section of oceanic crust became tilted, although this process was probably related to nearby basement tectonism described by Gohl et al. (1997).

Profile BAS923-25 shows no indication of sediment drifts or migrating sediment waves on this part of the continental rise, although a small channel is seen near the northern end of the line (near CMP 450, Fig. 2e).

\subsection{AWI-94042}

MCS profile AWI-94042 trends NNE-SSW and crosses the Antarctic continental shelf, slope and rise 


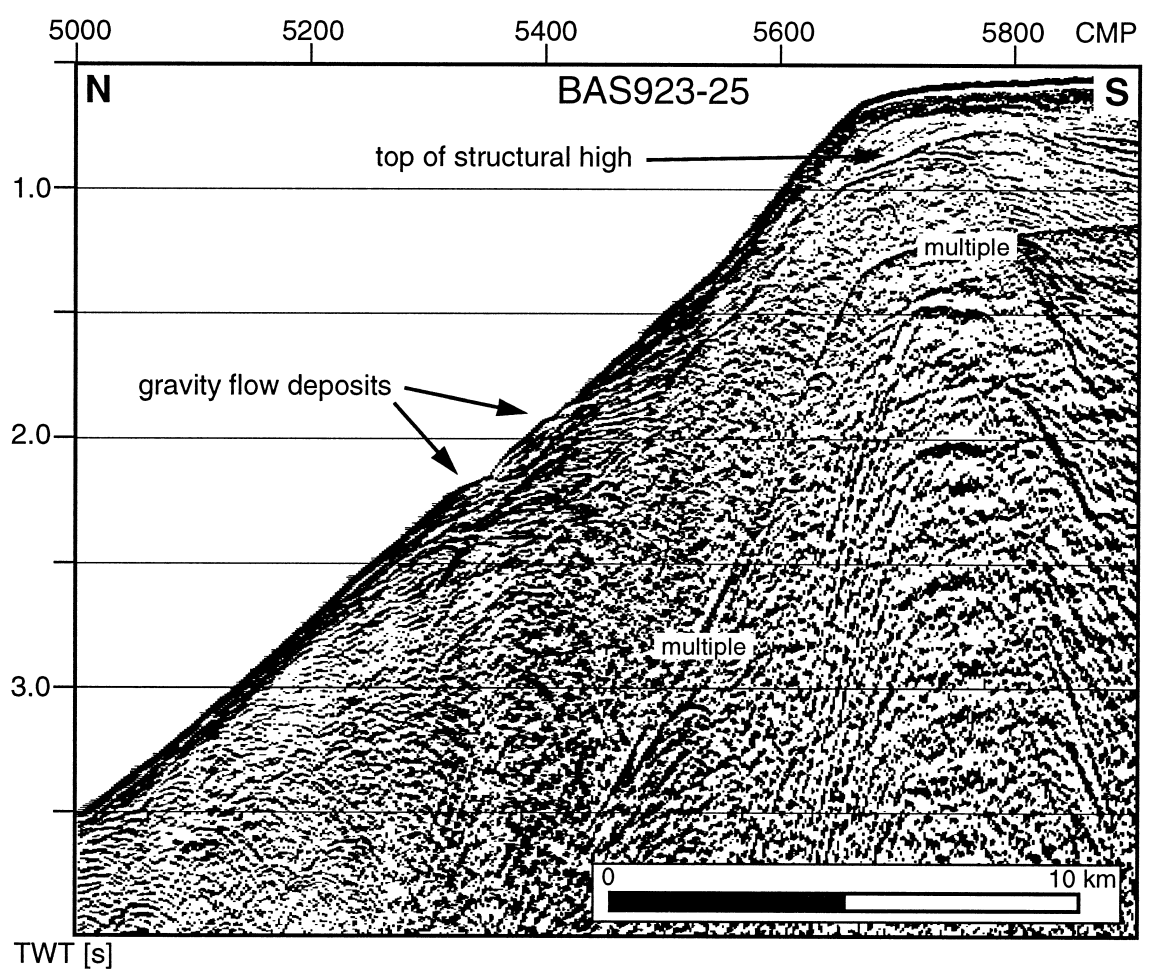

Fig. 7. Section from MCS profile BAS923-25 (located in Fig. 1) showing the outer continental shelf and slope near $97^{\circ} \mathrm{W}$. Vertical exaggeration is ca. $7: 1$ at the sea floor.

near $105^{\circ} \mathrm{W}$ (Figs. 1 and 2f). Profile AWI-94042 is the westernmost transect described in this study, and lies in the eastern part of the Amundsen Sea. Here, the continental shelf break lies $540 \mathrm{~m}$ below sea level, and the continental slope has a gradient of $3^{\circ}-4^{\circ}$. Unfavourable ice conditions during the MCS survey hampered data acquisition across the continental shelf, and AWI-94042 extended only $25 \mathrm{~km}$ landward of the shelf break. As a consequence, we are unable to properly distinguish separate acoustic units beneath the outer shelf on this profile. Nonetheless, AWI-94042 shows prograded foresets, which have been truncated by a series of sub-horizontal erosional unconformities (Fig. 2f, and shown in detail in Fig. 8 of Nitsche et al., 1997).

Farther north, MCS profile AWI-94042 and coincident sub-bottom Parasound data show several discrete, acoustically chaotic-transparent packages which are separated by bright, coherent reflections
(Fig. 8). We interpret these packages as debris flow deposits resulting from mass wasting of the upper slope. On the nearby continental rise, AWI-94042 shows mainly horizontally layered strata, although sediment mounds and channels are seen at depths of $<0.5$ STWT below sea floor. Swath bathymetry data show that the unburied channels form part of a single-channel system which meanders across the line as it runs northwards. A cross-section of this channel system is also seen at the western end of E-W profile AWI-94041 (Fig. 2g). We note that profile AWI-94042 and possibly profile BAS923-25 (Fig. 2e) cross the part of the Antarctic continental margin that separated from Chatham Rise ca. 80-90 $\mathrm{Ma}$ ago. This region forms the oldest oceanic province within the survey area, and therefore, the sediment record on this part of the rise may be expected to span a greater time interval than that seen on the more easterly profiles. 


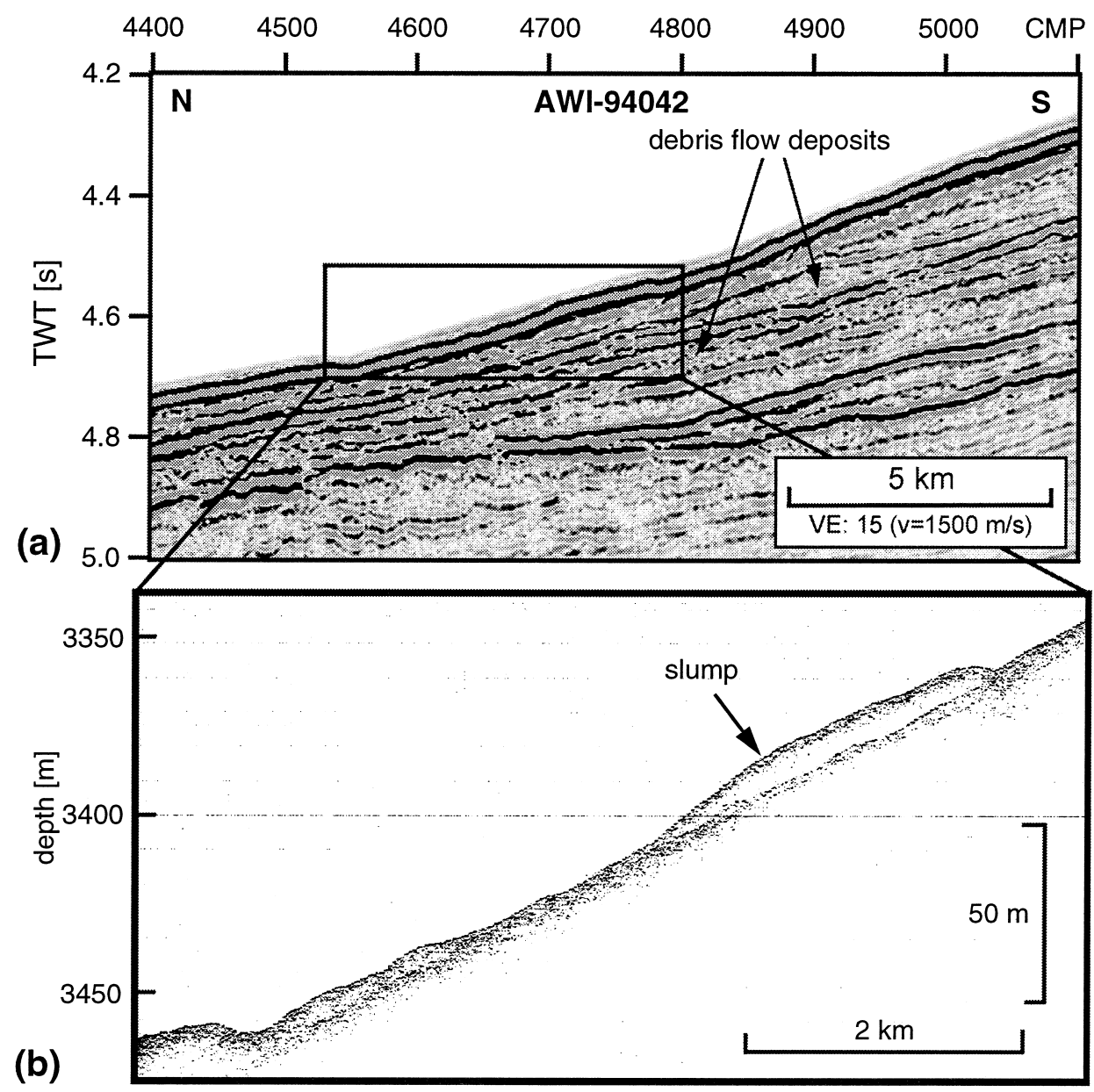

Fig. 8. (a) Section of MCS profile AWI-94042 (located in Fig. 1) showing debris flow deposits beneath the continental slope near $105^{\circ} \mathrm{W}$. Similar reflection patterns are seen on all slope transects crossing the area of investigation. (b) Part of the coincident Parasound high-resolution sub-bottom profile.

Some of the transects described above are connected by lines running parallel to the continental margin (Fig. 1).

\subsection{AWI-94041 / BAS923-24}

MCS profiles AWI-94041 and BAS923-24 are nearly coincident, and trend $\mathrm{E}-\mathrm{W}$ along $69^{\circ} 30^{\prime} \mathrm{S}$, parallel to the margin (Figs. 1 and $2 \mathrm{~g}$ ). These data show a large sediment mound or drift developed on the continental rise. The interpreted line drawing of profile AWI-94041 (Fig. 2g) shows the mound in relation to surrounding ocean floor, and a separate MCS data panel from profile BAS923-24 (Fig. 9) shows the internal acoustic architecture of the mound in detail.

Profile AWI-94041 shows that the sediment mound is built close to a large buried basement trough (centered on CMP 7800, Fig. 2g), where the oceanic crust to the east may have overridden crust to the west (Gohl et al., 1997). In particular, the mound developed above elevated crust to the east of the trough, and we suggest that uplift of this area may have contributed to the later formation of the mound. Here, profiles AWI-94041 and BAS923-24 show that early basement tectonism (described by Gohl et al., 1997) led to uplift of the ocean floor east of the trough, and the development of an erosional 


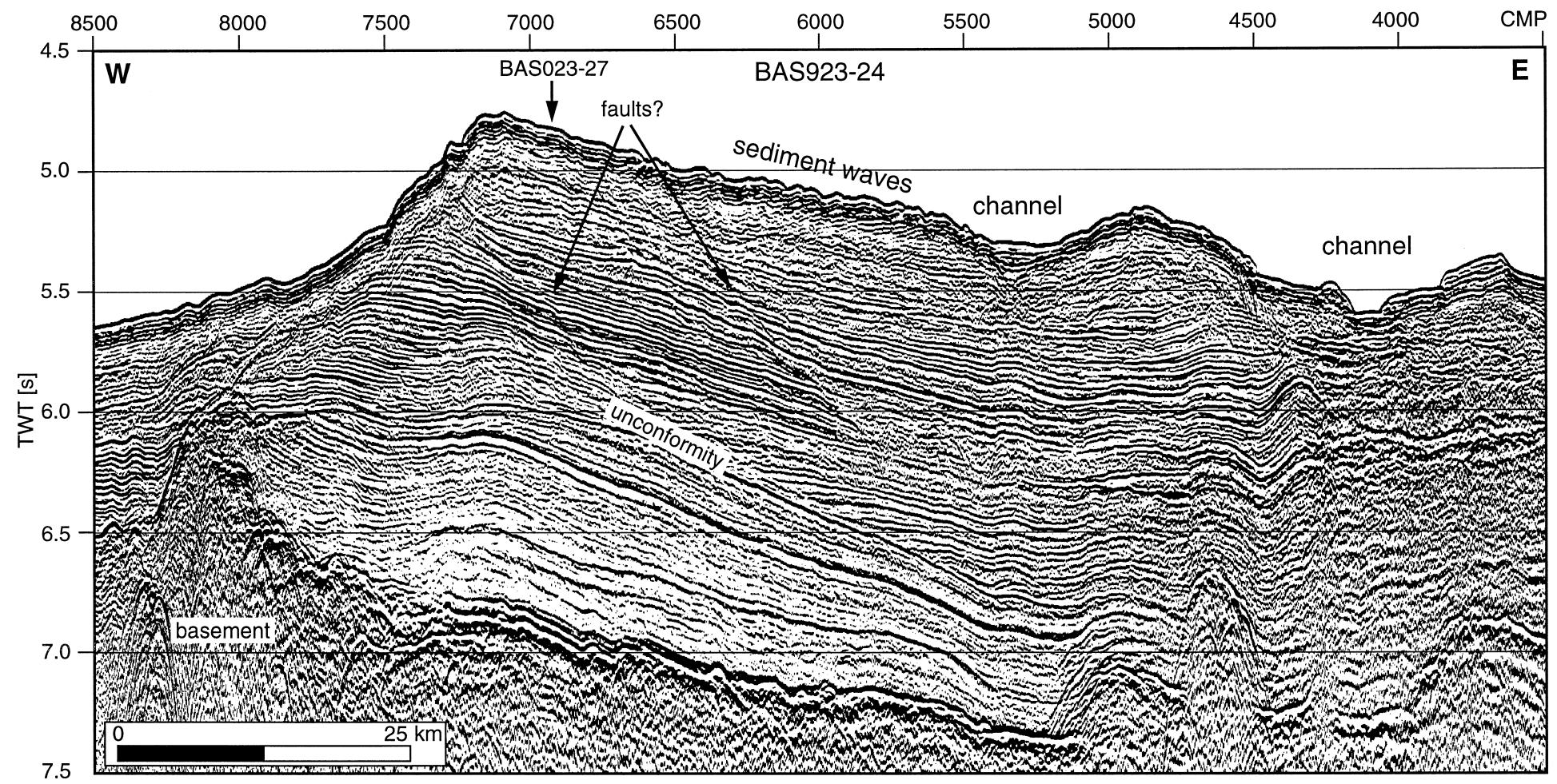

Fig. 9. Section of MCS profile BAS923-24 (located in Fig. 1) showing a large sediment mound on the continental rise near $94^{\circ} \mathrm{W}$. Vertical exaggeration is ca. $27: 1$ at the sea floor. 
unconformity (labelled at 6.1 STWT near CMP 6500, Fig. 9). This unconformity is seen also on N-S profile BAS923-27 (at ca. 6 STWT near the northern end of line, Fig. 2d). Onlap of post-tectonic sediments against this surface (e.g., at 6.7 STWT near CMP 5500, Fig. 9) indicates that a palaeo-high between ca. CMPs 7000 and 8200 existed during accumulation of these sediments. Profile BAS923-24 shows that the sediment mound has a width of ca. $100 \mathrm{~km}$ (extending between CMPs 4000 and 8000, Fig. 9), and that its crest rises ca. $700 \mathrm{~m}$ above the surrounding ocean floor (at CMP 7100, Fig. 9).
BAS923-24 also shows that the mound is asymmetric in cross-section, with a gentle eastern flank (east of CMP 7100) and a steeper western flank (west of CMP 7100). Two channels are developed on the eastern flank of the mound (centered on CMPs 4100 and 5300, Fig. 9), and sediment waves are clearly developed at its surface (between CMPs 5500 and 6200, Fig. 9).

An area of higher reflection amplitude beneath the easternmost channel (CMP 4000-4300, at about 5.7 STWT, Fig. 9) probably represents channel lag deposits, indicating that the position of the channel has

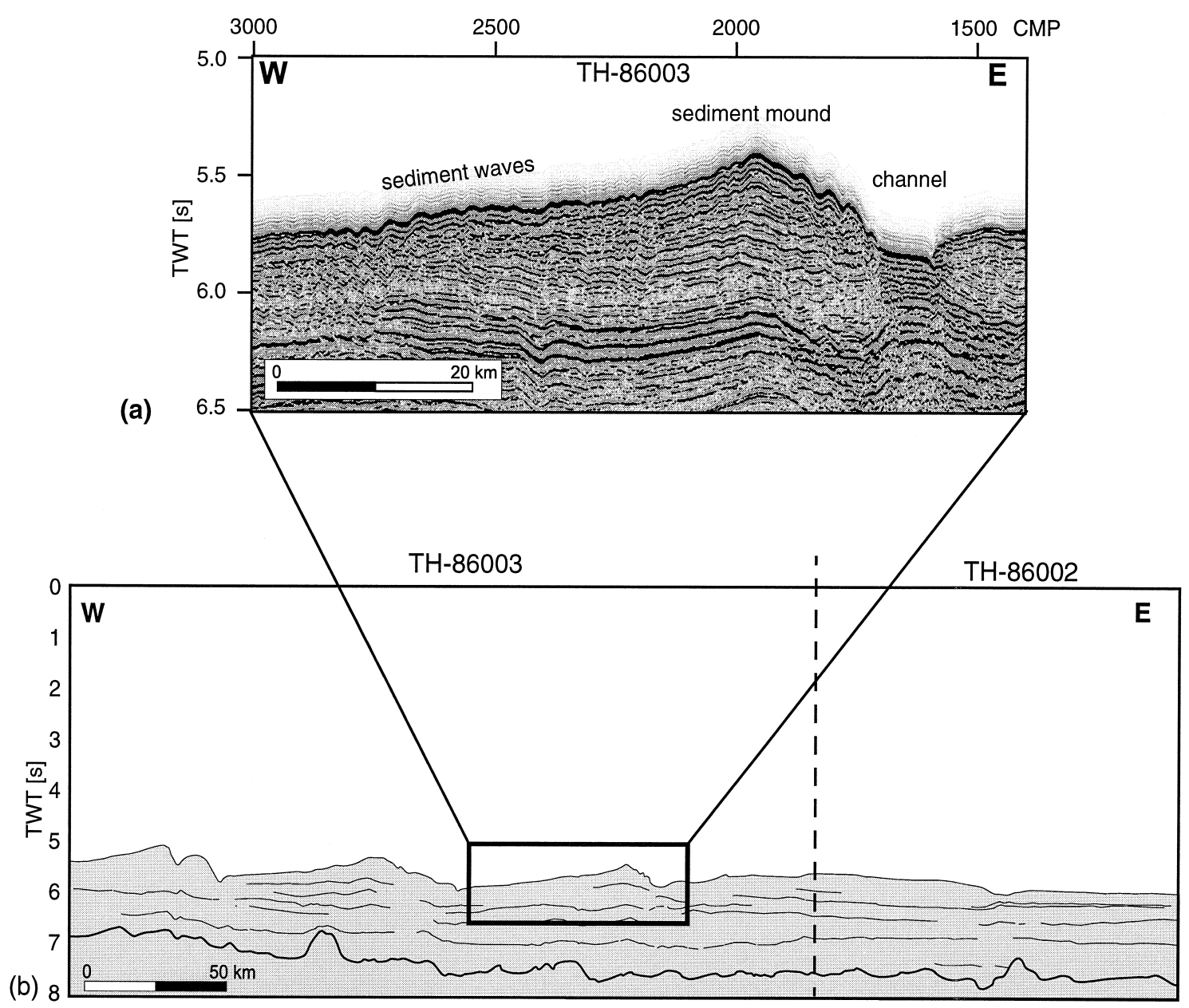

Fig. 10. MCS profiles TH-86002 and TH-86003 (located in Fig. 1) of JNOC. (a) Part of MCS profile TH-86003 showing one of the sediment mounds in detail. Vertical exaggeration is ca. 30:1 at the sea floor. (b) Interpreted line drawing of MCS profiles TH-86002 and TH-86003 showing (a) in relation to the surrounding sea floor. The thicker line indicates the top of the acoustic basement. Vertical exaggeration is ca. $24: 1$ at the sea floor. 
moved slightly to the west over time. This westward channel migration conflicts with observations of Tucholke and Houtz (1976), although their data extend across different parts of the Bellingshausen Sea, mostly farther offshore. MCS profiles AWI-94041 and BAS923-24 also show that the channels were probably generated later than a prominent reflection at about 6.2 STWT (CMP 4000, Fig. 9). Between this reflection and the underlying major unconformity, there is a sequence of reflections (maximum time-thickness of 0.5 STWT) which onlaps the unconformity. This suggests that the development of the channels and probably that of the mound took place quite some time after the tectonism that caused the unconformity.

West of the mound, MCS profiles AWI-94041 and BAS923-24 show a flat-lying seafloor, and near-surface sediments appear horizontally layered. Here, the uppermost sequences are intersected by a small channel at CMP 10100 and a larger channel at CMP 19500 (Fig. 2g). Unfortunately, reflections cannot be traced with confidence from one side of the mound to the other.

\subsection{Japan National Oil profiles}

Two additional MCS profiles, TH-86002 and TH86003 , collected by the JNOC have been included in this study. These lines have been published through the SCAR-database (Yamaguchi et al., 1988; SCAR, 1992). They trend parallel to the margin, across the lower continental rise in the Amundsen Sea (Figs. 1 and 10), and show a series of channels and sediment mounds (Fig. 10b). Fig. 10a (expanded part of profile TH-86003, Fig. 10b) is representative of these data and shows one of the sediment mounds in detail. Here, profile TH-86003 shows a mound which rises ca. $350 \mathrm{~m}$ above the surrounding seafloor, and has an apparent width of ca. $60 \mathrm{~km}$. This mound is smaller than the one seen to the east (e.g., on profiles AWI-94041 and BAS923-24, Fig. 9), although we note that this cross-section is farther away from the margin. This mound also differs from others described in this study because its eastern slope (which dips towards an adjacent channel) is more steeply dipping than its western slope. The gentle western slope has clearly defined sediment waves in its upper part. The mound is built above a strong reflection seen at ca. 6.2 STWT (Fig. 10a). Between CMPs 1600 and 1800, high-amplitude reflections indicate that the palaeo-position of the nearby channel has not migrated during the development of the mound.

\section{Discussion}

We have used the data described above, published echo sounding data (National Geophysical Data Center, 1996), and published data covering the eastern part of the area (McGinnis et al., 1997; Rebesco et al., 1997) to compile a map showing the distribution of channels, sediment mounds and seamounts in the Bellingshausen Sea region (Fig. 11). On this map, long thick arrows represent channels that have been interpolated between two or more bathymetry and/or seismic lines, assuming a straight or curvilinear path between ship tracks. Small thin arrows represent channels that have been identified on single lines only, or channels that cannot be traced confidently from line to line. In this case, the channel direction is assumed to trend directly down-slope (as defined by regional bathymetry data), although we recognise that some channels will trend obliquely across the continental rise. Hence, small arrows describe channel distribution rather than true channel paths.

The continental shelf break has been mapped from identifications on seismic or echo sounding profiles where such data exist. Elsewhere, the position of the shelf break has been inferred from the predicted topography of Smith and Sandwell (1997), although a lack of satellite data south of $72^{\circ} \mathrm{S}$ means that the position of the shelf edge remains uncertain in the Amundsen Sea. Seamounts and other outcropping basement structures are also marked where they have been identified on seismic lines. In the following discussion, we use these data to describe sedimentation processes operating on the continental shelf, slope and rise in the Bellingshausen and Amundsen Seas.

\subsection{Sedimentation processes on the continental shelf, slope and rise}

\subsubsection{The outer continental shelf}

As observed elsewhere on the Antarctic margin (Anderson et al., 1983; Larter and Barker, 1989; 


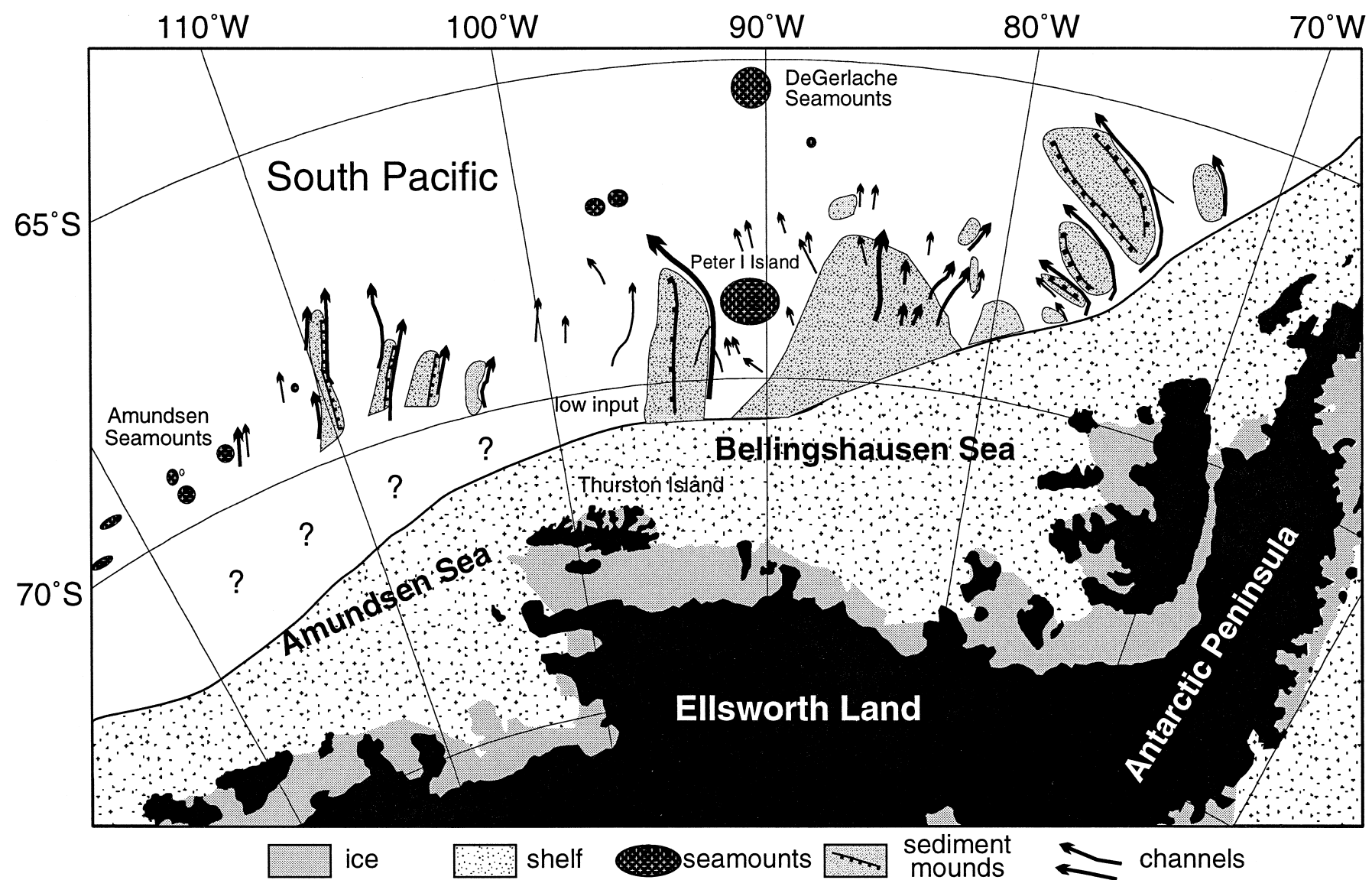

Fig. 11. Map showing the distribution of main sedimentary and bathymetric features mapped in the area of investigation including channels, sediment mounds and seamounts. The crests of major mounds are marked with a black line, and ticks mark the steeper flank of the mounds. The continental shelf break position has been derived from seismic profiles and bathymetry soundings, and interpolated from predicted bathymetry data (Smith and Sandwell, 1997) 
Cooper et al., 1991), the continental shelf in the Bellingshausen and Amundsen Seas is generally deeper (400-600 $\mathrm{m}$ below sea level) than that seen at lower latitudes. It is notable also, that profiles AWI-94002, AWI-94003, BAS923-22, AWI-94030 and AWI-94042 (Fig. 2a-c,f) show a gradual increase in water depth across the outermost continental shelf, landward of the shelf break. Most MCS profiles crossing the outer shelf show steep, prograded foresets which have been erosionally truncated by sub-horizontal unconformities. Similar characteristics have been reported on other parts of the Antarctic continental margin (e.g., Larter and Barker, 1989; Cooper et al., 1991), and have been interpreted as an indication of deposition by ice sheets grounded to the shelf edge during times of glacial maximum. These similarities lead us to conclude that grounded ice has reached the continental shelf edge many times on most parts of the Bellingshausen Sea margin. On several MCS profiles, the stratal geometry of sequences preserved beneath the outer shelf consists of three distinct units. The lower unit ' 1 ' (Nitsche et al., 1997) is characterised by gently dipping aggradational strata, and has a similar acoustic structure to the 'Type IIA' sequences of Cooper et al. (1991). These sequences were probably deposited in an environment where the West Antarctic ice sheet had not reached the present outer shelf; while glaciers or the ice sheet margin may have reached the sea, sediments were mainly transported across the continental shelf by marine and glacial marine processes. We attribute the change in geometry from unit 1 to overlying units ' 2 ' and ' 3 ' (Nitsche et al., 1997) to a fundamental change in the mechanism of sediment transport across the continental shelf. These upper units are characterised by more steeply dipping foreset reflections, which are usually less continuous than those of unit 1 , and are truncated by sub-horizontal unconformities at their upper limit. Units 2 and 3 have similar characteristics to the 'Type IA' sequences of Cooper et al. (1991). These sediments were probably transported at the base of an ice sheet and deposited where the ice lost contact with the sea floor, i.e., along the grounding line (Larter and Barker, 1989; Cooper et al., 1991; Powell and Alley, 1997). When the grounding line lay at or near the shelf edge, glacial sediments were deposited directly onto the upper slope, leading to the generation of foresets and shelf-edge progradation observed in the MCS profiles.

The stratal geometry of the outer shelf and the amount of progradation apparent within it may be considered a function of sediment supply and the rate of increase in accommodation space (the sum of shelf subsidence and sea level change) during the development of the prograded wedge. MCS profile BAS923-25 (Fig. 2e) also suggests local tectonic control on the development of the wedge. However, existing data do not allow us to properly separate these effects. On the basis of the regional tectonic framework (e.g., Mayes et al., 1990; McCarron and Larter, 1998), we expect the rate of thermal subsidence of the margin to increase gradually from west to east, in relation to the length of time since the last major thermo-tectonic event (rifting or ridge-trench collision). If we assume that the initial formation of the prograded wedge occurred after the start of the Miocene (by analogy with neighbouring areas: Larter and Barker, 1991b; De Santis et al., 1995), subsidence resulting from thermal effects should already have been relatively slow by that time along the entire Amundsen-Bellingshausen Seas margin. Therefore, there does not appear to be any reason why the rate of accommodation should have varied appreciably along the margin during its subsequent development. Hence, we surmise that variations in the total amount of progradation identified in the MCS data over distances of a few hundred kilometers are principally a function of sediment supply. Sediment supply to the margin would have been affected, in turn, by a variety of factors controlling the volume and dynamics of the ice sheet. An important factor would have been the focusing of sediment transport by ice streams, but data acquired on the continental shelf are still too sparse to identify source areas and transport patterns in this region.

The rate of sediment supply to the outer shelf would have fluctuated with variations in the distance between the ice grounding line and the continental shelf edge. When the grounding line advanced to the shelf edge, the ice sheet could have transported large volumes of poorly sorted material directly to the upper slope. However, when the grounding line lay significantly inshore, some finer-grained sediment might have been transported to the outer shelf and slope by tidal motion and shelf currents, but most 
glacial sediments were probably trapped within the deeper inner shelf area.

MCS profiles presented in this study show alongmargin variation in the acoustic architecture of the outer shelf, and the amount of shelf-edge progradation. Spatial variations in the size of the prograded wedge are also suggested by predicted bathymetry data (Smith and Sandwell, 1997) which show 'lobes' similar to those shown to have been produced by progradation along the Antarctic Peninsula (Larter et al., 1997). The lobate form of the margin appears to be confirmed by the few bathymetry tracks available in the area. On MCS profile BAS923-25 (Fig. 2e and Fig. 7), prograded sequences appear to be absent, which may suggest low sediment supply to the shelf edge. Here, nearby Thurston Island (Fig. 1) might have acted as a barrier to ice streams supplying sediment from the West Antarctic continent. It is possible also, that the local structural high observed beneath the outer shelf (near CMP 5750, Fig. 7) restricted sediment transport to this part of the upper slope. At its southern end, profile BAS923-25 is connected to BAS923-27 by E-W MCS profile BAS923-26, extending along the continental shelf (unpublished BAS data). BAS923-26 extends obliquely across prograded sequences just a few kilometers east of line BAS923-25. Hence, we infer that the absence of prograded foresets on profile BAS923-25 is of local extent, although additional data are required to confirm this.

\subsubsection{The continental slope}

Seismic transects presented in this study (Fig. 2) show a marked difference in continental slope gradient between profile AWI-94002 and the other lines. Easternmost profile AWI-94002 shows a much steeper gradient $\left(>12^{\circ}\right.$, Fig. 2a) than the more westerly transects $\left(2^{\circ}-5^{\circ}\right.$, Fig. $\left.2 b-d, f\right)$. This steep slope gradient is typical of many published profiles from the Pacific margin of the Antarctic Peninsula (Larter and Barker, 1989, 1991b). We consider two possible factors that may have contributed to this difference. Firstly, the present variation in slope angle may partly reflect along-slope variations that pre-date deposition from grounded ice and are the result of older tectonic processes. Antarctic-Phoenix ridge segments migrated into the trench west of $80^{\circ} \mathrm{W}$ before $40 \mathrm{Ma}$, but did not reach the part of the margin east of $80^{\circ} \mathrm{W}$ until after $30 \mathrm{Ma}$ (Larter et al., 1997; McCarron and Larter, 1998). As a consequence of changes in subduction convergence rate and direction, changes in spreading rate, and possible microplate tectonics during the early Tertiary, the last stages of subduction might have had different effects on these different sectors of the margin. Slope gradient may also have been affected by the textural composition of the glacial sediment supplied to the margin. Larter and Barker (1989) suggested that the immaturity (poor sorting and particle roughness) of glacial sediment might be a factor in the apparent stability of the steep Antarctic Peninsula slope. We note that the glacial transport path from Ellsworth Land to the Bellingshausen Sea margin is considerably longer than equivalent paths in the Antarctic Peninsula region. Prolonged shearing in a deforming basal till may break up some of the coarser fraction of the till and therefore increase the degree of sorting. Hence, if sorting occurs by this means, and if sediment texture is indeed a factor in slope stability on glacial margins, then the longer transport path in the Bellingshausen Sea would result in a lower slope angle. It is interesting to note that the Antarctic continental slope has a relatively low gradient $\left(1^{\circ}-3^{\circ}\right)$ in other places where long glacial transport paths reached the margin at times of glacial maximum, e.g., eastern Ross Sea, Crary Fan and Prydz Channel Fan (Haugland et al., 1985; Cooper et al., 1991).

Variations in sediment composition may also be related to variations in sea-floor reflection strength observed on BAS and AWI MCS profiles. A comparison of MCS profiles crossing the continental shelf in the Bellingshausen Sea and Antarctic Peninsula regions suggests that sea-floor multiple reflections are weaker in the Bellingshausen Sea, which implies a lower sea-floor reflection coefficient in this region. This is consistent with estimates of interval velocities for shallow shelf sediments derived from semblance analyses during processing, which are typically $>2000 \mathrm{~m} \mathrm{~s}^{-1}$ in the Antarctic Peninsula region (Larter and Barker, 1989), but only 1800 $1900 \mathrm{~m} \mathrm{~s}^{-1}$ in the Bellingshausen Sea. If sediments deposited on the outer shelf in the Bellingshausen Sea are, on average, finer-grained, they would tend to retain more water, and this would explain the slightly lower seismic velocities, resulting in a lower reflection coefficient at the sea floor. Alternatively, 
the lower seismic velocities for shallow shelf sediments in the Bellingshausen Sea could indicate that they have been subject to less glacial loading and compaction.

Published studies (Rebesco et al., 1997) have shown that sediment drifts on the continental rise near the Antarctic Peninsula are separated from the continental margin by non-depositional bathymetric troughs which extend along the foot of the continental slope. In contrast, the larger sediment mounds in the Bellingshausen Sea form topographic ridges which extend to the continental margin (Fig. 11, and shown by MCS profile BAS923-27, Fig. 2d). The absence of a non-depositional trough at the base of slope may be related to the difference in continental slope gradient described above. Very high energy gravity flows generated on the steep slope of the Antarctic Peninsula margin may have eroded drift sediments near the base of the slope. However, in the Bellingshausen Sea, the continental slope is shallower, and down-slope gravity flows may be less energetic, leading to sediment preservation at the base of slope. Rebesco et al. (1997) also described drift sediments which onlap the lower slope adjacent to their lobe '2', and suggested that this part of the Antarctic Peninsula margin had been less active during recent glaciations. Hence, we suggest that preservation of sediments on the lower continental slope may be controlled, in part, by the energy of downslope gravity flows generated during times of glacial maximum.

MCS profiles BAS923-22 and AWI-94030 show acoustically laminated units which onlap the upper continental palaeo-slope (Fig. 6). This geometry could reflect hemipelagic deposition in the presence of a contour current on the slope. Predicted bathymetry data (Smith and Sandwell, 1997) suggest that here, the upper slope forms part of a broad sediment ridge, with its crest lying farther to the east (between $85^{\circ} \mathrm{W}$ and $87^{\circ} \mathrm{W}$, Fig. 1). The unusual landward movement of the palaeo-shelf edge in profile BAS923-22 shows that the rate of increase in accommodation space outstripped sediment supply to this part of the margin at least once during the growth of the prograded wedge. Hence, there have been times when the sediment input from the inner shelf to this flank of the sediment ridge near $87^{\circ} 30^{\prime} \mathrm{W}$ appears to have been comparatively low. This has led to the preservation of slope facies which were probably sourced along-slope to the east.

Farther west, the depositional pattern of sediments beneath the outer shelf remains poorly defined. However, the acoustic architecture of MCS profile AWI94042 suggests that grounded ice has, at some time, reached the continental shelf edge and transported sediment to the upper slope in the eastern Amundsen Sea.

Along most parts of the continental margin investigated in this study, MCS and high-resolution subbottom profiles show evidence of small-scale slope failure and debris flow deposits (e.g., profile AWI94042, Fig. 8). However, we find no evidence of sub-marine canyons along the continental shelf edge and slope on the existing margin crossings. This observation conflicts with results of a previous study based on older and more poorly located bathymetric soundings (Vanney and Johnson, 1976) that showed canyons for which we have found no supporting evidence.

The channels seen in BAS and AWI profile data appear to extend northward from the foot of the continental slope (Fig. 11). This is shown in swath bathymetry data acquired north of Alexander Island (Figs. 1 and 12). On the upper continental slope, these data show numerous small gullies and scarps, whereas central parts of the slope have a comparatively smooth sea floor. At greater depth, elongated mounds are seen near the base of slope. Between the mounds, small channels merge together to form larger channels on the upper continental rise. Similar features have been seen in GLORIA sonographs of the Antarctic Peninsula margin (Tomlinson et al., 1992).

\subsubsection{The continental rise}

On the continental rise, we have identified a series of sediment mounds and intervening channels (Fig. 11). The mounds are usually located along the western side of the channels, consistent with observations of Tucholke and Houtz (1976). In places where channels lie along both sides of a mound, the mound is thought to have been built up from sediment supplied through the more easterly channel.

Turbidites in sediment cores from the abyssal plains (Hollister et al., 1976; Wright et al., 1983) suggest that the rise channels formed pathways for turbidity currents, and it is likely that the intervening 


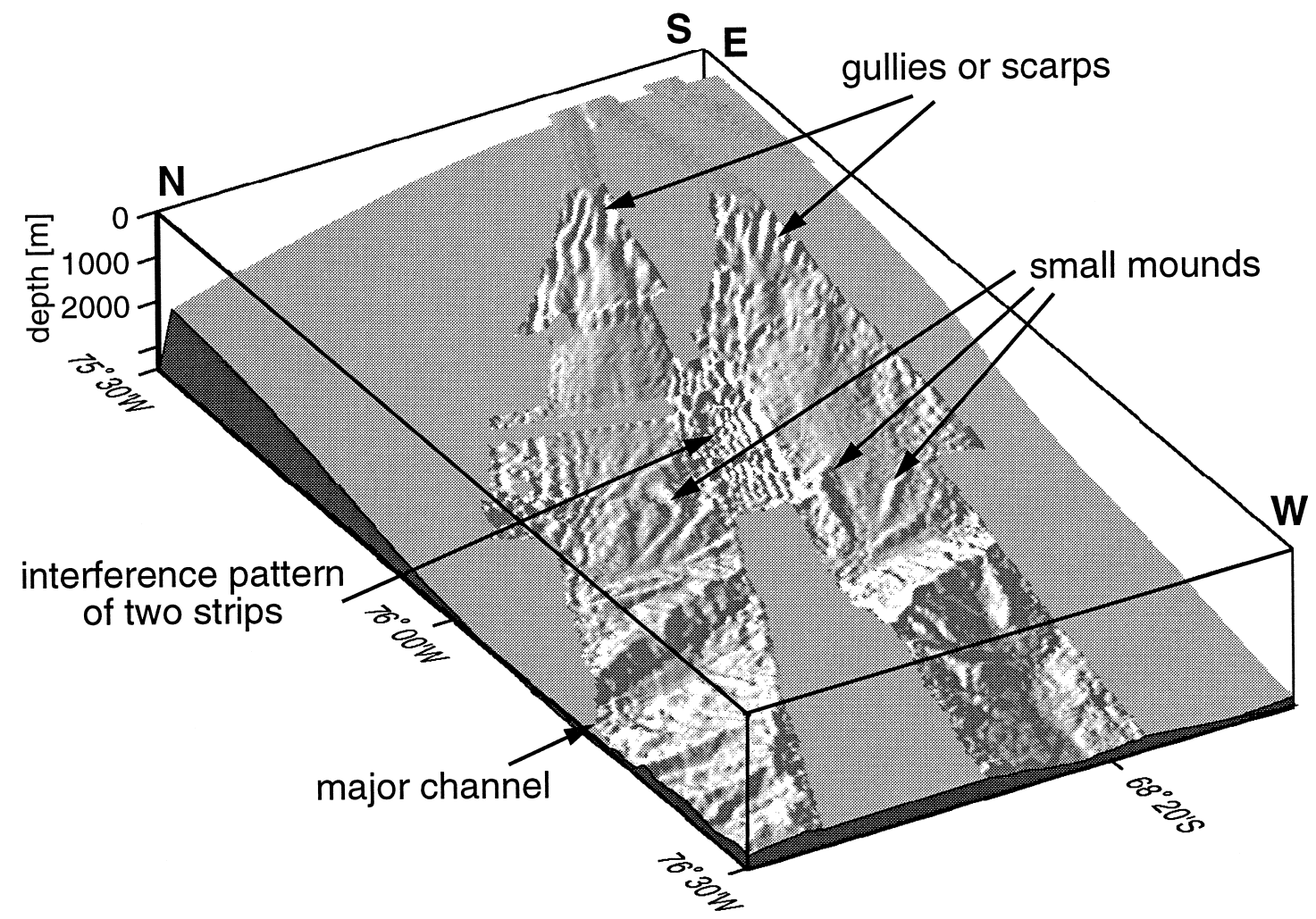

Fig. 12. Perspective view of two Hydrosweep swath bathymetry stripes from the continental slope north of Alexander Island (located in Fig. 1 , and illuminated from NE). These data show small channels on the lower continental slope merging to form the major channel which separates the large mound in the foreground from the continental slope.

sediment mounds are composed primarily of finegrained components from these turbidity currents which were entrained in ambient bottom currents. The fact, that mounds or levees are usually seen on the western sides of the channels, can be explained by deposition in the presence of a westward-flowing bottom current and Coriolis force (e.g., Tucholke, 1977; Rebesco et al., 1996). Variations in the shape and size of the mounds along the margin could reflect differences in the influence of the bottom current and sediment supply: while the mound on profiles BAS923-24/AWI-94030 (Fig. 9) has a similar acoustic architecture to sediment drifts on the rise to the northeast (e.g., Rebesco et al., 1996), the geometry of the mounds on profile TH-86003 (Fig. 10) more closely resembles that of a classical channel levee (as described by Stow, 1994). Direct oceanographic measurements (e.g., Hellmer et al., 1998) are sparse in this region, and do not describe bottom current flow in the vicinity of the sediment mounds; as a consequence, the bottom current regime in the southern Bellingshausen and Amundsen Seas remains poorly understood. Nonetheless, westwardflowing ambient bottom currents have been inferred previously on the basis of seabed photographs (Hollister and Heezen, 1967) and nepheloid measurements (Tucholke, 1977). The nearest published direct current measurements at the South Shetland trench (Nowlin and Zenk, 1988) and on the rise north of the Antarctic Peninsula (Camerlenghi et al., 1997) describe westward bottom current flow, with speeds decreasing southwestward from $10-20 \mathrm{~cm} \mathrm{~s}^{-1}$ at the South Shetland trench to ca. $6 \mathrm{~cm} \mathrm{~s}^{-1}$ near $77^{\circ} \mathrm{W}$. In addition to a westward-flowing boundary current, the action of Coriolis force on turbidity currents would also promote deposition along the western side of the channels. However, the vertical relief of some mounds described in this study is larger than that of 
any channel levees reported in areas lacking significant bottom current activity. It is possible also, that bottom circulation varied appreciably during past glacial cycles. In particular, Pudsey (1992) proposed weaker bottom currents during glacial periods in the Weddell Sea, which is presumed to be the source area for bottom water flowing westward along the Antarctic Peninsula margin and Bellingshausen Sea continental rise.

Farther north, sedimentation processes are thought to be dominated by the Antarctic Circumpolar Current (ACC, e.g., Nowlin and Klinck, 1986), which is wind-forced at the sea surface, and affects the entire water column. ACC flow probably began after the opening of Drake Passage ca. 23 Ma ago (Barker and Burrell, 1977). In the eastern Bellingshausen Sea, Read et al. (1995) showed that the modern ACC extends as far south as $67^{\circ} \mathrm{S}$.

Seismic reflection and high-resolution sub-bottom profiles presented here and elsewhere (e.g., Tucholke, 1977) show well-formed migrating sediment waves on the rise in the Bellingshausen Sea. Sediment waves have been associated with ambient thermohaline current flow across sediment drifts (Flood et al., 1993) and turbidity current flow across deepsea channel levees (e.g., Damuth, 1979; Normark et al., 1980; Carter et al., 1990). Comparison of BAS and AWI profile data suggests that sediment waves are more common on the continental rise in the
Bellingshausen and Amundsen Seas than on the rise adjacent to the Antarctic Peninsula. This may be due, in part, to the existing distribution of data; sediment waves described in this study are located farther away from the margin (100-200 km) than most MCS profiles obtained in the Antarctic Peninsula region. Hence, it is possible that sediment waves have not been widely reported in the Antarctic Peninsula region due to the lack of data over distal parts of the rise. Alternatively, it is possible that the characteristics of the sediment (e.g., grain size or cohesion) or the bottom currents (e.g., speed or directional stability) favour sediment wave formation in the Bellingshausen Sea.

\subsection{Glacial margin sedimentation model}

The sedimentation processes described above can be incorporated into a preliminary sedimentation model for the glacial margin depositional systems in the Bellingshausen Sea (shown in perspective view, Fig. 13). Before a large ice sheet developed on West Antarctica, the main sedimentation processes were probably similar to those found on lower latitude margins. When ice sheets first reached the open sea, marine and glacial marine processes were probably still the main means of sediment transport across the continental shelf. During subsequent glacial-interglacial cycles, the advance and retreat of grounded

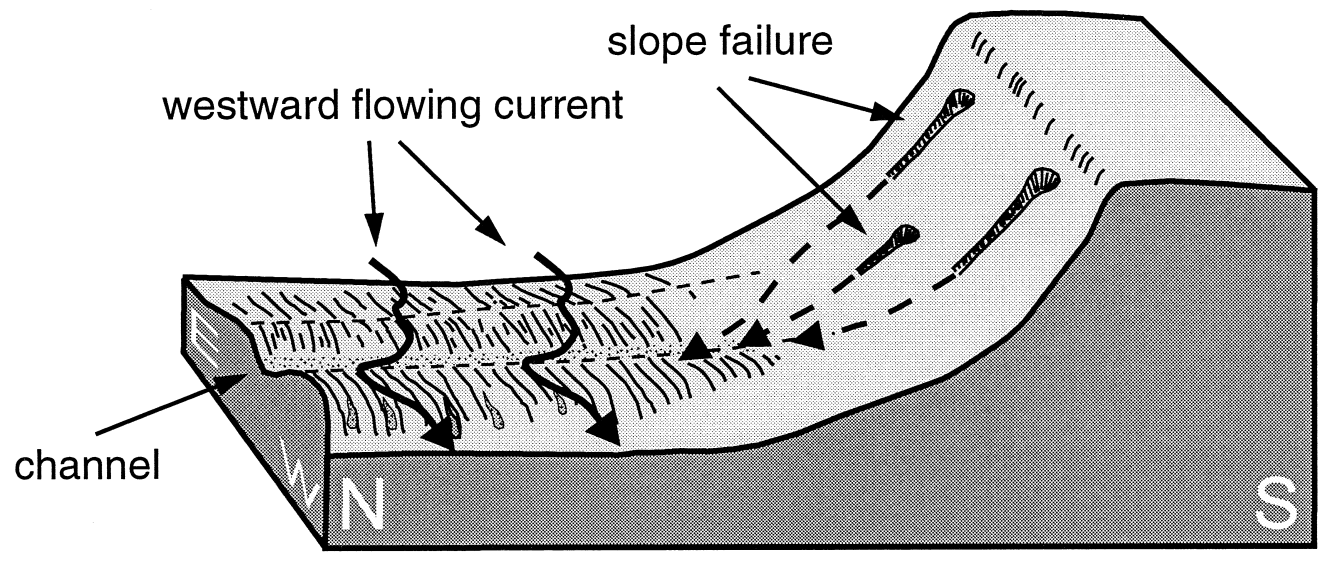

Fig. 13. Simple model describing sedimentation processes in the Bellingshausen Sea. 
ice sheets across the continental shelf would have resulted in a fundamental change in the shelfslope-rise sediment transport system. At glacial maximum, grounded ice probably reached the shelf edge in many parts of the Bellingshausen and Amundsen Seas, which would have caused an increase in the supply of terrigenous material to the upper slope. Sediment supply would have been especially high in the vicinity of ice stream termini. This was probably accompanied by increased sediment transport down the continental slope by means of small-scale slumps and debris flows. While the coarsest fraction settled on the lower slope, other components were probably incorporated in turbidity currents which flowed along the channels on the continental rise toward the abyssal plain. Sediment preservation on the uppermost rise may have been controlled, in part, by the energy of subsequent down-slope flows. MCS and sub-bottom profiles suggest that slumps and debris flows have been generated on a broad part of the slope, and that remobilised material has been transported in tributary channels which meet near the base of slope to form major channels on the rise. Here, fine-grained components from turbidity currents have settled mainly on the western bank of the channels, having been entrained in westward-flowing bottom currents and deflected by Coriolis force. We note that mounds are closely associated with channels (Fig. 11), and that appreciable volumes of terrigenous sediment have been deposited in the vicinity of channels. Similar mounds have been found to the northeast, on the Antarctic Peninsula rise (McGinnis and Hayes, 1995; Rebesco et al., 1996, 1997; McGinnis et al., 1997). Rebesco et al. (1996) interpret these mounds as sediment drifts, constructed mainly from the finegrained components of turbidity currents originating on the continental slope, entrained in a nepheloid layer within the ambient southwesterly bottom currents, and deposited downcurrent. In contrast, McGinnis and Hayes (1995) and McGinnis et al. (1997) suggest that the mounds were generated mainly by down-slope depositional processes with less influence of bottom currents. From our data, we surmise that long-distance nepheloid layer transport at the base of the westward-flowing boundary current has played a comparatively minor role on the rise in the Bellingshausen and Amundsen Seas, al- though in some places, bottom currents have had a major influence on the pattern of deposition of finegrained terrigenous sediment, and hence, on construction of mounds. Our model seeks to account for the wide range of depositional styles observed on the continental shelf, slope and rise in this region through variations in sediment supply, and the strength and stability of bottom currents.

The BAS and AWI MCS profiles in the Bellingshausen and Amundsen Seas do not extend through drill sites, and consequently, we have no reliable constraints on the age of the prograded sequences described in this study. Existing studies suggest that grounded ice reached the continental shelf edge in the eastern Ross Sea by the early Miocene (De Santis et al., 1995), and reached the shelf edge in the Antarctic Peninsula region in the latest Miocene (Larter et al., 1997). In the absence of reliable age control, the timing of the onset of glacial progradation in the Bellingshausen and Amundsen Seas remains uncertain, although we suspect that it falls within the Miocene. While uncertainties remain concerning the regional significance of stratal geometry transitions within the depositional sequences observed beneath the outer continental shelf, thick drift accumulations identified on the adjacent continental rise may still yield a palaeo-environmental record which is representative of the region as a whole. Existing studies suggest that the acoustic stratigraphy of rise drifts may be jump-correlated over large distances (i.e., $400 \mathrm{~km}$, Rebesco et al., 1997), and that these sediment bodies provide a more continuous sedimentary record.

Owing to a paucity of data, the morphology and depositional architecture of the shelf and slope in the central Amundsen Sea remains poorly understood. Predicted bathymetry data (Smith and Sandwell, 1997) and one available bathymetry profile suggest that canyons may be present in the upper slope between $108^{\circ} \mathrm{W}$ and $112^{\circ} \mathrm{W}$. JNOC MCS profiles (Fig. 10) show channels, mounds and sediment waves on the continental rise similar to those in the Bellingshausen Sea, which suggests that similar sedimentation processes have been active in both areas. Differences in the geometry of the mounds observed on the JNOC profiles from those in the Bellingshausen Sea suggest a lesser influence of westward-flowing bottom currents. This could result from a westward 
decrease in bottom current velocity, or a decrease in bottom current velocity with increasing distance from the margin. Additional data are required to resolve this uncertainty.

\section{Conclusions}

In this study, we present new MCS profiles, high-resolution sub-bottom profiles and bathymetry data acquired across a remote and poorly surveyed part of the Antarctic margin in the Bellingshausen and Amundsen Seas. These data show regional variations in the depositional style of the Antarctic continental margin. Some specific findings are listed below.

(1) Although there are some general similarities in the stratal geometry of shelf sequences, MCS data also show longitudinal variations in the development of depositional systems on the Antarctic continental shelf, slope and rise in the Bellingshausen and Amundsen Seas. Comparison between data acquired in the Bellingshausen Sea and Antarctic Peninsula regions also shows similar overall patterns of shelf sequences, as well as demonstrating differences in detail between the development history of the margin in these areas. These differences result from a variety of factors which affect southern-hemisphere glacial margin sedimentation including: variations in source lithology, the rate of sediment supply to the outer shelf, the length of the glacial transport path, local tectonic controls, and the influence of bottom currents on sedimentation.

(2) On most MCS profiles crossing the outer continental shelf, we identify a broad transition from gently dipping aggradational sequences, to sequences with more steeply dipping prograded foresets, which are truncated at their upper limit by sub-horizontal unconformities. By analogy with previous studies, we suggest that the lower aggradational sequences were deposited in a glacial marine environment where the West Antarctic ice sheet had not reached the present outer shelf, and that the upper progradational sequences were deposited at or near the shelf edge by grounded ice during times of glacial maximum. MCS profiles also show large variations in the amount of shelf edge progradation over distances of a few hundred kilometers. We suspect that this prin- cipally reflects variations in sediment supply to the outer shelf, which would have been affected, in turn, by the geology of the glacial catchment area and other factors controlling the dynamics of the West Antarctic ice sheet.

(3) Near $87^{\circ} 30^{\prime} \mathrm{W}$, MCS profiles crossing the Antarctic continental margin show a thick, currentinfluenced slope sequence on the upper continental slope. Here also, an abrupt landward shift of the offlap break is observed within progradational/aggradational sequences beneath the adjacent outer shelf. We infer from these observations that there have been times when sediment input from the inner shelf was comparatively low along this part of the margin. Elsewhere in the Bellingshausen Sea and Antarctic Peninsula regions, equivalent slope-front facies are thought to have been overwhelmed by sediments transported along the shelf-slope-rise sediment transport path.

(4) We identify sediment mounds developed on the upper continental rise. We interpret these mounds as being principally composed of fine-grained material which has been transported to the rise by turbidity currents. Coriolis force will have influenced turbidity currents throughout the region, but the size and shape of one mound in the western Bellingshausen Sea implies that entrainment of fine-grained sediments in westward-flowing ambient bottom currents was important in this area. Similar bottom current influence on mound construction to the northeast on the Antarctic Peninsula continental rise has been proposed by McGinnis and Hayes (1995), Rebesco et al. (1996; 1997), and McGinnis et al. (1997), although their models differ with regard to the relative influence of these currents. We consider that the distribution, structure and external form of the mounds in the Amundsen and Bellingshausen Seas reflect the relative influence of the bottom currents, and the nature and volume of sediment supplied from the adjacent continental margin.

This study shows that sedimentation processes on the Antarctic continental shelf, slope and rise are affected by many physical and environmental factors. In order to distinguish these effects, the whole sediment transport path from shelf to slope to rise must be understood. Additional insights may be gained from comparisons with northern-hemisphere glacial margin systems. 


\section{Acknowledgements}

We thank the captains, crews and scientists of the cruises of the RRS James Clark Ross and RV Polarstern on which the data used in this paper were collected. We also thank Peter Barker and the reviewers, G. Leitchenkov and A. Maldonado, for thoughtful comments. This is AWI contribution No. 1512 .

\section{References}

Anderson, J.B., Brake, C., Domack, E.W., Myers, N., Singer, J., 1983. Sedimentary dynamics of the Antarctic continental shelf. In: Oliver, R.L., James, P.R., Jago, J.B. (Eds.), Antarctic Earth Science. Australian Academy of Science, Canberra, pp. 387389.

Barker, P.F., Burrell, J., 1977. The opening of the Drake Passage. Marine Geology 25, 15-34.

Bart, P.J., Anderson, J.B., 1995. Seismic record of glacial events affecting the Pacific margin of the northwestern Antarctic Peninsula. In: Cooper, A.K., Barker, P.F., Brancolini, G. (Eds.), Geology and Seismic Stratigraphy of the Antarctic Margin. Antarctic Research Series, Vol. 68. American Geophysical Union, Washington, DC, pp. 75-95.

Camerlenghi, A., Crise, A., Pudsey, C.J., Accerboni, E., Laterza, R., Rebesco, M., 1997. Ten-month observation of the bottom current regime across a sediment drift of the Pacific margin of the Antarctic Peninsula. Antarctic Science 9, 426-433.

Carter, L., Carter, R.M., Nelson, C.S., Fulthorpe, C.S., Neil, H.L., 1990. Evolution of Pliocene to recent abyssal sediment waves on Bounty Channel levees, New Zealand. Marine Geology 95, 97-109.

Cooper, A.K., Webb, P.N., 1992. International offshore studies on Antarctic Cenozoic history, glaciation, and sea-level change: the ANTOSTRAT project. In: Yoshida, Y., Kaminuma, K., Shiraishi, K. (Eds.), Recent Progress in Antarctic Earth Science. Terra Scientific Publishing, Tokyo, pp. 655-659.

Cooper, A.K., Barrett, P., Hinz, K., Traube, V., Leitchenkov, G., Stagg, H., 1991. Cenozoic prograding sequences of the Antarctic continental margin: a record of glacio-eustatic and tectonic events. Marine Geology 102, 175-213.

Cunningham, A.P., Larter, R.D., Barker, P.F., 1994. Glacially prograded sequences on the Bellingshausen Sea continental margin near $90^{\circ} \mathrm{W}$. Terra Antartica 1, 267-268.

Damuth, J.E., 1979. Migrating sediment waves created by turbidity currents in the northern South China Basin. Geology 7, 520-523.

De Santis, L., Anderson, J.B., Brancolini, G., Zayatz, I., 1995. Seismic record of late Oligocene through Miocene glaciation on the central and eastern continental shelf of the Ross Sea. In: Cooper, A.K., Barker, P.F., Brancolini, G. (Eds.), Geology and Seismic Stratigraphy of the Antarctic Margin. Antarctic Research Series, Vol. 71. American Geophysical Union, Washington, DC, pp. 235-260.
Flood, R.D., Shor, A.N., Manley, P.D., 1993. Morphology of abyssal mudwaves at Project Mudwaves sites in the Argentine Basin. Deep-Sea Research II 40, 859-888.

Gohl, K., Nitsche, F.O., Miller, H., 1997. Seismic and gravity data reveal Tertiary interplate subduction in the Bellingshausen Sea, Southeast Pacific. Geology 25, 371-374.

Haugland, K., Kristoffersen, Y., Velde, A., 1985. Seismic investigations in the Weddell Sea embayment. Tectonophysics 114, 293-313.

Hellmer, H.H., Jacobs, S.S., Jenkins, A., 1998. Oceanic erosion of a floating Antarctic glacier in the Amundsen Sea. In: Jacobs, S., Weiss, R. (Eds.), Ocean, Ice, and Atmosphere: Interactions at the Antarctic Continental Margin. Antarctic Research Series, Vol. 75. American Geophysical Union, Washington, DC, pp. 83-99.

Hollister, C.D., Heezen, B.C., 1967. The sea floor of the Bellingshausen Sea. In: Hersey, J.B. (Ed.), Deep-Sea Photography. Johns Hopkins Univ. Press, Baltimore, MD, pp. 177-189.

Hollister, C.D., Craddock, C., et al., 1976. Initial Reports of the Deep-Sea Drilling Project, Vol. 35. US Government Printing Office, Washington, DC, $929 \mathrm{pp}$.

Kuvaas, B., Leitchenkov, G., 1992. Glaciomarine turbidite and current controlled deposits in Prydz Bay, Antarctica. Marine Geology 108, 365-381.

Larter, R.D., Barker, P.F., 1989. Seismic stratigraphy of the Antarctic Peninsula Pacific margin: a record of PliocenePleistocene ice volume and palaeoclimate. Geology 17, 731734.

Larter, R.D., Barker, P.F., 1991a. Effects of ridge crest-trench interaction on Antarctic-Phoenix spreading: forces on a young subducting plate. J. Geophys. Res. 96B, 19583-19607.

Larter, R.D., Barker, P.F., 1991. Neogene interaction of tectonic and glacial processes at the Pacific margin of the Antarctic Peninsula. In: Macdonald, D.I.M. (Ed.), Sedimentation, Tectonics and Eustasy, Vol. 12. Int. Assoc. Sedimentol. Spec. Publ., pp. 165-186.

Larter, R.D., Cunningham, A.P., 1993. The depositional pattern and distribution of glacial-interglacial sequences on the Antarctic Peninsula Pacific margin. Marine Geology 109, 203-219.

Larter, R.D., Rebesco, M., Vanneste, L.E., Gambôa, L.A.P., Barker, P.F., 1997. Cenozoic tectonic, sedimentary and glacial history of the continental shelf west of Graham Land, Antarctic Peninsula. In: Barker, P.F., Cooper, A.K. (Eds.), Geology and Seismic Stratigraphy of the Antarctic margin: 2. Antarctic Research Series, Vol. 71. American Geophysical Union, Washington, DC, pp. 1-27.

Mammerickx, J., Cande, S., 1982. General Bathymetric Charts of the Oceans (GEBCO), Vol. 515. Canadian Hydrographic Survey, Ottawa.

Mayes, C.L., Lawver, L.A., Sandwell, D.T., 1990. Tectonic history and new isochron chart of the South Pacific. J. Geophys. Res. 95B, 8543-8567.

McCarron, J.J., Larter, R.D., 1998. Late Cretaceous to early Tertiary subduction history of the Antarctic Peninsula. Journal of the Geological Society $155,255-258$.

McGinnis, J.P., Hayes, D.E., 1995. The role of downslope and 
along-slope depositional processes: southern Antarctic Peninsula continental rise. In: Cooper, A.K., Barker, P.F., Brancolini, G. (Eds.), Geology and Seismic Stratigraphy of the Antarctic Margin. Antarctic Research Series, Vol. 68. American Geophysical Union, Washington, DC, pp. 141-156.

McGinnis, J.P., Hayes, D.E., Driscoll, N.W., 1997. Sedimentary processes across the continental rise of the southern Antarctic Peninsula. Marine Geology 141, 91-109.

Miller, H., Grobe, H., 1996. The expedition ANTARKTIS-XI/3 of RV 'Polarstern' 1994. Berichte zur Polarforschung, Vol. $188,115 \mathrm{pp}$.

Miller, K.G., Fairbanks, R.G., Mountain, G.S., 1987. Tertiary oxygen isotope synthesis, sea-level history, and continental margin erosion. Palaeoceanography 2, 1-19.

Moons, A., DeBatist, M., Henriet, J.P., Miller, H., 1992. Sequence stratigraphy of the Crary Fan, Southeastern Weddell Sea. In: Yoshida, Y., Kaminuma, K., Shiraishi, K. (Eds.), Recent Progress in Antarctic Earth Science, Tokyo. Terra Scientific Publishing, Tokyo, pp. 613-618.

National Geophysical Data Center, 1996. Marine Geophysical trackline data (GEODAS /TRACKDAS). Data Announcement 96-MGG-01, Natl. Oceanic Atmos. Admin. US Dept. Commer., Boulder, CO.

Nitsche, F.O., Gohl, K., Vanneste, K., Miller, H., 1997. Seismic expression of glacially deposited sequences in the Bellingshausen and Amundsen Seas, West Antarctica. In: Barker, P.F., Cooper, A.K. (Eds.), Geology and Seismic Stratigraphy of the Antarctic Margin: 2. Antarctic Research Series, Vol. 71. American Geophysical Union, Washington, DC, pp. 95-108.

Normark, W.R., Hess, G.R., Stow, D.A.V., Bowen, A.J., 1980. Sediment waves on the Monterey Fan levee: a preliminary physical interpretation. Marine Geology 37, 1-18.

Nowlin, W.D., Klinck, J.M., 1986. The physics of the Antarctic Circumpolar Current. Reviews of Geophysics 24, 469-491.

Nowlin, W.D., Zenk, W., 1988. Westward bottom currents along the margin of the South Shetland Island Arc. Deep-Sea Research 35, 269-301.

Powell, R.D., Alley, R.B., 1997. Grounding-line systems: processes, glaciological inferences and the stratigraphic record. In: Barker, P.F., Cooper, A.K. (Eds.), Geology and Seismic Stratigraphy of the Antarctic Margin: 2. Antarctic Research Series, Vol. 71. American Geophysical Union, Washington, DC, pp. 169-142.

Pudsey, C.J., 1992. Late Quaternary changes in Antarctic bottom water velocity inferred from sediment grain size in the northern Weddell Sea. Marine Geology 107, 9-33.

Read, J.F., Pollard, R.T., Morrison, A.I., Symon, C., 1995. On the southerly extent of the Antarctic Circumpolar Current in the southeast Pacific. Deep-Sea Research II 42, 933-954.

Rebesco, M., Larter, R.D., Camerlenghi, A., Barker, P.F., 1996. Giant sediment drifts on the continental rise west of Antarctic Peninsula. Geo-Marine Letters 16, 65-75.

Rebesco, M., Larter, R.D., Barker, P.F., Camerlenghi, A., Vanneste, L.E., 1997. The history of sedimentation on the continental rise west of Antarctic Peninsula. In: Barker, P.F., Cooper, A.K. (Eds.), Geology and Seismic Stratigraphy of the Antarctic Margin: 2. Antarctic Research Series, Vol. 71. American Geophysical Union, Washington, DC, pp. 29-49.

SCAR, 1992. A SCAR seismic data library system for cooperative research: summary of the international workshop on Antarctic seismic data. SCAR Report No. 9, Scott Polar Research Institute, Cambridge, 15 pp.

Smith, W.H.F., Sandwell, D.T., 1997. Global seafloor topography from satellite altimetry and ship depth soundings. Science 277, 1956-1962.

Stow, D.A.V., 1994. Deep-sea processes of sediment transport and deposition. In: Pye, K. (Ed.), Sediment Transport and Depositional Processes. Blackwell, Oxford, pp. 257-291.

Tomlinson, J.S., Pudsey, C.J., Livermore, R.A., Larter, R.D., Barker, P.F., 1992. Long-range sidescan sonar (GLORIA) survey of the Antarctic Peninsula pacific margin. In: Yoshida, Y., Kaminuma, K., Shiraishi, K. (Eds.), Recent Progress in Antarctic Earth Science. Terra Scientific Publishing, Tokyo, pp. $423-429$.

Tucholke, B.E., 1977. Sedimentation processes and acoustic stratigraphy in the Bellingshausen Basin. Marine Geology 25, 209-230.

Tucholke, B.E., Houtz, R.E., 1976. Sedimentary framework of the Bellingshausen Basin from seismic profiler data. In: Hollister, C.D., et al. (Eds.), Initial Reports of the Deep Sea Drilling Project, Vol. 35. US Government Printing Office, Washington, DC, pp. 197-227.

Vanney, J.R., Johnson, G.L., 1976. The Bellingshausen-Amundsen basins (southeastern Pacific): major sea-floor units and problems. Marine Geology 22, 71-101.

Wright, R., Anderson, J.B., Fisco, P.P., 1983. Distribution and association of sediment gravity flow deposits and glacial/glacial marine sediments around the continental margin of Antarctica. In: Molina, B.F. (Ed.), Glacial Marine Sedimentation. Plenum, New York, pp. 265-300.

Yamaguchi, K., Tamura, Y., Mizukosho, I., Tsuru, I., 1988. Preliminary report of geophysical and geological surveys in the Amundsen Sea, West Antarctica. Proc. NIPR Symp. Antarctic Geosci. 2, 55-67. 